University of Louisville

ThinkIR: The University of Louisville's Institutional Repository

Electronic Theses and Dissertations

1932

\title{
Josephus as an historian.
}

Charles Ber Chavel 1906-1982

University of Louisville

Follow this and additional works at: https://ir.library.louisville.edu/etd

Part of the History of Religion Commons, and the Intellectual History Commons

\section{Recommended Citation}

Chavel, Charles Ber 1906-1982, "Josephus as an historian." (1932). Electronic Theses and Dissertations. Paper 1690.

https://doi.org/10.18297/etd/1690

This Master's Thesis is brought to you for free and open access by ThinkIR: The University of Louisville's Institutional Repository. It has been accepted for inclusion in Electronic Theses and Dissertations by an authorized administrator of ThinkIR: The University of Louisville's Institutional Repository. This title appears here courtesy of the author, who has retained all other copyrights. For more information, please contact thinkir@louisville.edu. 
UNIVERSITY OF LOULSILLE

JUSEHHUS AS AN HISTORIAN

A Dissertation

submitted to the Faculty

Uf the Graduate School of the university of Louisville

In rartial fulfillment of the

Kequirements for the Degree

Uf Master of Arts

Departinent of History

By

Charles B. Chavel

1932 
TABLE OF COHTENTS 
PREFACE...............................

I. INTRODUCTION $\ldots \ldots \ldots \ldots \ldots \ldots \ldots \ldots \ldots \ldots \ldots \ldots \ldots$

A. Spirit of the Time.................... I

(a) Pharisees and Sadducees............... 1-8

(b) Sketch of Chief Historical Events....... 9-20

(c) Incompatibility of Roman Spirit and Jewish Life............... 20-26

B. Life of Josephus...................... 26

(a) In Palestino................... 26-37

(b) In Rome...................... 37-43

c. Character........................... 43-47

II. POINTS OF THESIS..................... 48

A. and B. Facts and Judgnents. "Slips"......... 49-60

C. Josephus not a Phariser.................. 60-65

III. PRINCIPLES OF HISTORIOGRAPHY.............66

A. Sources.......................... 66

(a) General Pre-Josephean............... 67-73

(b) Partioular Sources for Wars and

(c) Extent and Wethod of Josephus' Way of using sources................ 78-86

B. Point of View: Motives and Prejudices........ 87.

(a) Immediate Motives................ 87

1. Flavian..................... 87-94

2. Herodian........................ 94-96

3. Personal........................ 97-99

4. Roman...................... 99-100

5. Jewish...................... 100-104 
CONPENTS



1. Pure Historical Intentions of Antiquities................ 105-109

c. Credibility........................ 110

D. Rationality....................... 110-113

E. Sperches.......................... 114-115

F. Chronology ....................... 115-118

G. Some Unsolved Problems................ 118-121

IV. CONCEPTION OF HISTORY................. 122

A. Criticism of Greek Historiography......... 123-126

B. History As It Should Be witten.......... 126-I28

C. Assistants. Style. Literary Value........ 128-13l

V. RELATIVE POSITION OF JOSEPHUS AMONG CLASSICAL

HISTORIANS .......................... 132-134

VI. SUMMARY........................... 135

BIBLIOGRAPHY....................... 138 
PREFACE 


\section{PREFACE}

A study of Josophus as a historian hardly calls for an apology. Josephus, though he may not attain in his works the epio vision of a historian as Herodotus, or the political insight of Thucydides, yet consummates the traditions and labors of an epoch. The first centuries before and after the Common Era, so momentous in the history of mankind, are nowhere so sharply and tensely mirrored as in the pages of Josephus. A glance at a bibliography in any language on the literature of Josephus will further convinoe one that the subject is by no means antiquarian. It is consequently not an apology that is noeded, but a conclse exposition as to how a study of Josephus as a historian will be conducive to a general study in historiography.

In the first place, a study of Josephus helps to direct one's attention to a potentially-fruitful perspective of history. Generally, the tendenoy among historians is to view history from the standpoint of its agents -. the men and nations that have been the makers of history. The historian follows the steeds of the ceesars and other men of action, and views things as these leaders saw them. It is natural for hin to do so, because writing after centuries have elapsed since the event he describes, and knowing the outcome of the issue, he is equipped with an added item of knowledge which the original experience in the flux did not possess. He knows how to differentiate the victor from the 
vanquished, and regards them as such from the start. But it is noedless to point out, that there is an additional party, besides the active, to any historical event. There is that group or nation upon whom the event had been wrought, i.e., the passive element. To construct history from its standpoint would be, I think, a highly instructive adventure. Thus, to follow in Mormsen's history of Rome, the progressive march of rax Komane in the Mediterranean world, is after all to see only one half of the pleture. But, one wonders, what was life in a province? How did the people there look upon Rome, and react to its standard of civilization? It is seldom that the works of a historian afford such rare opportunity along that line as do those of Josephus. In reading them, one lives mentally in a province of the Roman Empire, and looks out upon its teeming activity. Here and there, the perspective may shift--for Josephus, as we shall later soe, writes often from a Roman point of view--but generally, the picture remains as aforesaid. A study of Josephus is thus conducive to the recognition of a possibly new perspective in historiography. Secondly, it reveals many items of importance regarding social conditions of these times. Historiography, during the Roman Empire, had not risen yet to a consciousness of the social element in history. A recognition of the 
political element was its highest achievement.

To reconstruct the history of those times in the full synthetic sense of the modern conception of history, ancient works must be searched for indirect data, bearing upon these aspects of Roman life. In this quest, a study of Josephus is of great consequence. The large KomanHellenistic cities with their factional strifes, the noisy Greek and Jewish elements, and a host of other indirect sidelights of similar interest are in no contemporary source seen so olearly as here.

Intimate glimpses into the ancient historian's workshop can also be caught here. His staff of assistants oan almost be identified; and his criticism of Greek and Roman historiography presents in a suocinct fashion the conflicting schools of history of his time.

Of paramount interest is Josephus still from another angle, namely, the decline of the old pagan order in the Koman tmpire, and the gradual penetration of Christianity. There is no doubt of the faot that the spread of this new Religion proved in the course of years to be one of the many contributing causes in the transformation of the Roman Empire. The channels through which the pagan world derived

* see below pp. 120-121 
its knowledge of the elements of Hebraic history must have naturally colored its conoeption of the newlyconquering religion. The Septuagint was one source of that kind, and Josephus another. A study of his work, imparts, therefore, a good bit of insight into one of the fundementel sources which pre-conditioned the decline of Paganism, and shaped the nature and essence of the now religious order.

Finally, the works of Josephus retain an interest on the basis of their own merit. The story of any nation is important if its account is one of conflicts and development of values--political, social, religious, etc. That the theme of Josephus' task is of such a nature, no one will question. Josephus as a man is, furthermore, a highly instructive study. He is the first historian to have written an autobiography, in the strict sense of the word. He is the first ancient historian, regarding whose life and character there is the most abundant, and almost thoroughgoing material.

These, in short, are the historiographical aspects that are indirectly touched upon by our study. To be sure, the object of this paper is not to confine itself to these points; the endeavor here in the preface was only to demonstrate the general pragmatic value there is behind this paper--the delineation of Josephus as a historian. 
The plan of the paper requires no specific comment save the fact that wherever contentious are of my own reasoning - as in the points of thesis, motives, etc. $i$ have aimed at abundance of proof. On the other hand, points of fact which are taken from sources are mentioned but are not elaborated in detail.

Also, in the introduction, there are a few historical facts which could have been omitted, but were given place there so as to serve as a basis of forthooming discussion in the paper. 
I. INTRODUCTION 
I. INTRODUCTION

A. Spirit of the Time

The life of our historian, as it affects the nature, soope, and limitations of his works, goes deeply down into the environment of his times, which in turn is a resultant of causal factors, past and present. To understand, therefore, fully the forces at work in the life of Josephus as a historian, we must retrace our steps to visualize threo fundamental factors, constituting the spirit of the time. These are: (a) Pharisees and sadducees, (b) Chief historical events, (c) The incompatibility of Roman Spirit and Jewish Life.

\section{(a) Pharisees and sadducees}

The most conspicuous inner development in the history of israel, during the second Comnonwealth--a development of momentous consequence in the history of that entire period-is the rise of the tharisers and the sadduceos.

The traditional view of the Pharisees is well known. It can be seen in any dictionary, where the word is given as a synonym for a hypoorite. The causes of this unfair, and damaging, historical judgment we need not enter into; but that the truth was far away from this conception, a group of recent historians have now slowly and definitely established. The new tendency is seen best in Herford (1)

R. T. Herford, Pharisaism, and The Pharisees. 
and Hoore. (2) The picture they draw of the typical Pharisees, and of the origin and development of the movement they fostered is clear, definite, and convincing.

Pharisaism in its simple stages began its rise with Ezra, who returning from Babylon (458 B.C.) began, with royal authority to reform the new Jersalem community that had formed around the newly-built second Temple. His original impelling motive was to establish religious duties as the personal concern of every individual man. (3) Whereas formerly, knowledge was a prerogative solely of the priestly class, the masses remaining in ignorance of duties and standards established by lawgivers and prophets, Ezra brought down religious knowledge to the realm of the ordinary man. He required that every man should be in a position to know what was contained in the Torah, and that he should fulfill it in his daily life. "What Ezra did was to lay a much greater emphasis upon the need of obedience to what was contained in the book of Torah as being the duty of every 1sraelite." (4) It was not that Ezra broke away from prophetic teachings, aiming to establish a rigid legalism; on the contrary, it

G. F. Moore, Judaism. (4)

Herford, tharisaism, p. 11 .

Lbid., p. 62 . 
was an attempt to bring down prophetic principles within the sphere of activity of daily life. "He came forward to enforce their (the prophets') teaching, to apply it, and to get from it a larger result of practical righteousness than it had produced in their time."

The center of leadership was immediately affected. It shifted from control by an aristocratic priesthood to that of a popular democratic body. for by making scriptures and other religious knowledge the possession of the people, a democratization of religion was inevitable. "Ihe tharisees were essentially a democratic party in the sense that they were themselves mainly drawn from the people, and safeguarded the religious rights and privileges of the laity as against the aristocratic and exclusive priesthood." ${ }^{(6)}$

In harmony with its primary aim, Hharisaism also encouraged the development of the synagogue, with its emphasis on personal prayer and piety, as over against formalistic tendencies of the Temple. This creation again was a further impetus towards the democratization of religion. for while there could be only one Temple for sacrifices in Jerusalem, with an exclusive priesthood officiating, a

(5)

Herford, tharisaism, p. 65

Hastings Encyc. of kel. and Uthios, art. "Hharisees", p. 834. 
synogogue could be built in every village, with any educated man to lead it in prayer or scripture reading. For the first time in the world's history, congregational worship appeared. (7) The spirit of sabbaths and joyous festivals could thus easily be brought through the locel synagogues into the homes of people located far away from the sanctuary in Jerusalem. "Whereas by the conservative priesthood, such (Sabbath) oocasions were regarded mainly as Temple festivals, the tharisees strove to bring them into the common life of the people." ${ }^{(8)}$

The theoretical basis of Pharisalsm was supplied by its theory of Torah (Knowledge) and the establishnent of the authority of the oral law. The effect of making the written Bible the indisputable guide of all conduct soon made it ovident to the early Hharisaic leaders that lifo is always far ahead of any written dooument, that the latter does not in fact supply sufficient guidance for all occasions. The method they were forced to adopt was, therefore, to study the written word, extract the essenoe of its spirit, and apply it to new problems. soon, this practice established many oral traditions and interpretations, which became as authoritative as those of the written law. Rules of exegesis (7) (8)

Herford, Pharisaism, p. 79 .

Hastings Encyc. of Rel. and kthics, art. "Phariseos", p. 834 . 
were perfected, and religious laws constantly harmonized (9)

with the need of new conditions. Thus, "an eye for an eye" was interpreted, through a manipulation of exegetio principles, to mean "money for an eye". In general, a theory of Porah was developed which made every discovery of new thought in the realm of knowledge a successive unfolding of what had been originally hidden in the written letter. "By tharisaism, the element of evolution and progress was injected into the law." (10)

Personalism, democracy, religious progress - these then wore the factors that characterized Pharisaism as a movement. As such, it is easy to perceive how unjust the historicel verdict has been on the Pharisees. "A body which thus placed the knowledge and the ministrations of religion into the hands of the people, cannot have been that self-seeking and obscurantist sect which traditional ignorance represents the Pharisees to have been." (12) That in certain individuals, the morement at times tended towards a formalism, is of no serious indictment; for all conceptions if overemphasized are apt to be misused. At the heart of the average thariseo, (9) Moore, Judaism, i, p. 80.

(10) Hastings Encyo. of Religion and Ethics, art. "Pharisees", p. 834. (11) "Denunciation of this kind (of the pharisees by the New Testament writers) was of course not based on a careful and critical study of the views of those who were denounced... its form was derived from the human nature which was quite as strong in the christian as in the Jew." Herford, The Pharisees, pp. 214-215.

(12) r. Goodman, A History of the Jews, p. 24. 
however, "there was the pioty which sought and found God in the worship of the symagogue and the home, which looked to $\mathrm{Him}$ with love and humble trust, and knew Him to be not far off but very near, no mere abstract power, no hard taskmaster, but the Heavenly f'ather."

The influence the Pharisees exerted over the people (14)

was at no time shaken. They maintained their spiritual hegemony not only because they were themselves recruited from the masses, but chiefly that the people trusted in their leadership. Hence, even the services in the Temple, around which rallied the sadducees, were conducted according to their teachings, for otherwise the people would not have tolerated them. In a way, the Phariseos were not a party in the strict sense of the term, but represented the bulk (15) of the nation.

The sadducees, on the other hand, were really a party. Primarily a social class, they were not united for religious interests, but solely to face the aggressive and popular party which threatened their position. In the course of time, as they sought for the ruling power, they too assooiated themselves with a definite religious tendency. (16) They came to (13)

(14) Herford, tharisaism, p. 110.

(14) Schurer, History of Jewish reople, $11^{2}$, p. 28.

(15) $\perp$ bid., $11^{2}$, p. 28

Moore, Judaism, i, p. 70 . 
represent the old conservative position of the priesthood-aiming at the control of the Temple by the wealthy class, challenging the authority of the oral law, and denying the teachings of the Pharisees as regards the immortality of the soul, freedom of the will and providence over the individuel. They were the representatives of the old archaic religious notions, negating centuries of Jewish development. Essentially, it could be demonstrated that the sadducees lacked any fundamental attachment to religion at (18)

al1. For denying freedom of the will, they minimized personal responsibility; challenging the doctrine of Providenoe, they would assert that every man was his lord; and questioning the immortality of the soul, they denied reward and punishment. The basis of any considerable meaning to be attached to religion was thus removed. It is no wonder that the sadducees appear in the sources as greedy, avaricious of power, shifting their allegiance to wherever the wind blew for mercenary and political gain.

The nature of the two leading parties, tharisees and sadducees, is thus clear. The one embodied the new demooratic tendency, championed religious progress, placed emphasis on the personal element in religious life, and was not ready "of making concessions to political exigencies at the expense (17)

Schurer, History of Jewish Yeople, $11^{2}, \mathrm{pp} .34,38$.

Halevi, Doros Harishonim 1, p. 393 . 
of religion;" $"$ the other hung on tenaciously to old aristocratic prerogatives, stressed the immobility of the written letter, placed emphasis on worldly matters, and was ready to forego religious rights for the benefit of political advantages.

The heat of the struggle that went on between the two factions for control of government and Temple was thus motivated by real issues, and not, as has been fornerly supposed, by mere confliots of harraless dogma. The essence of conflicts in states is practically the same in all ages and countries; only the form under which the issues appear differs. In Judaea, due to certain historic factors that go back to the first kingdoms, the terms happened to be religious. But the form did not hinder other vital issues--political, social, and economic--from being involved as well.

There was still a third group - the Hssenes. But as these were of an ascetic tendency, living in communes far away from the stirring problems of the day, they exerted no direot influence upon the course of events. (20) The center of internal activity during the second Commonwealth was thus to be found concentrated on issues between the popular and aristocratic parties--Pharisees and sadducees. (I9) (20) Waxman, History of Jewish Literature, p. 57 . Herford, Yharisaism, p. 46. 
(b) Sketch of Uhief Historidal Events

The Jewish rebellion against the Symian Greeks wich in the end won for the ${ }_{1}^{\text {pols }}$ political independence was in the main a religious revolt. its object in the start was not political independence but religious freedom. As conditions changed, and the former object was made the goal of the national endeavor, the flushing success brought with it swoeping results. The old theocratic self-sufficiency of the Judaean community had to give way to pressing problems and policies of goverment. Palestine, which had been until then a negligible state, indistinguishable within the great Persian Empire, unrecognized by Greek writers during the early Hellenistic period, was suddenly raised into an independent kingdom of distinotion. (22) The struggle brought with it the spirit of a heroio age--the poriod of the Haccabees. But at the same time, it brought new problems of organization to the front. should the new state go on developing on lines of the theocratic system of Ezra, or should it allow itself to drift into a secural policy of political expansion, waging war, etc., similar to that of all other states?

(21)

Herford, Yharisaism, p. 39 .

J. Klausner, Jesus of Nazareth, pp. 135-136. 
During the reign of the first independent Hasmonean ruler, simon, the conflicting elements were still latent; the joy of the newly-won independence was yet too great to give prominence to difference of opinion. In the ensuing reign, however, of John Hyrcanus, the secularization policy, with its attempt of unlimited territorial expansion, had gone too far to please the tharisaic element. The prince was obliged to comnence looking for support of his policies to the wealthy families; a gradual alienation between the pharisees and the ruler was started. The definite breach occured in the middle of his reign, when Hyrcanus allied himself with the sadducean element, "abrogated the ordinances the Pharisees had established, and punished those who observed them." (23)

The gradual estrangement between the bulk of the people and the rulers was bound to follow. It gathered momentum in the short reign of Aristobolus 1 , who concluded the secularization policy by officially assuming the title king. That was a fatal step. The first ruler, simon, was oareful to avoid it; he was only the Nasi, the prince. For since he was not a decendant of David, also because he held the office of High priest, he found it to be prudent not to combine the two functions in one person. with Aristobolus'

$$
\text { Moore, Judalsm, i, p. } 58 .
$$


restoration of the official monarchy, which in itself was an unwise step, and further procedure to combine secular and priestly authority in the king--the now policies ultimately proved to the disadvantage of both Temple and state. "The two offices were quite incompatible, the ideals of the one being fundamentally different from the other. It invested the priesthood with the glamour of wealth and worldly power, which alienated it from the sympathies, the respect and the attachment of the mass of the people." Later on, in the Roman period, the two offices were again separated; but the mischief done could no longer be checked. The high priesthood, having lost its sanctity in the eyes of the people, became an object of barter, a political tool in the hands of irresponsible leaders. The people, estranged from the rulers, were bound to compensate their loss by turaing to the popular leaders--the Pharisees. In the period of Alexander Janneus, the oppesition came to open conflict. For six years the king with foreign troops fought against his poople. The struggle ended in the intimidation of the people, the assassination of 800 leaders, and the flight of the great Pharisaic leaders to Egypt and

$\frac{\text { Judaism and the Beginning of Uhristianity, art. "Jewish }}{\text { History", p. 15. }}$ 
other countries.

Two decades the king and his nobles

ruled against the interests of the people.

Before his death, he repented, and advised his wife, Alexandra, to make peace with his $1 i f e-l o n g$ enemies. Accordingly, she reinstituted the complete tharisaic order to its old prominence in the state. Upposition ceased, the leaders of the people assumed control, and an era of peace and relative prosperity followed.

But it was not for long. Immediately after Alexandra's death, her two sons, Aristobolus 11 and Hyrcanus 1 , caused a civil war. Of the two, Hyrcanus was the senior; but as Aristobolus was of a more aggressive and a worldly type of character than his brother, the sadducean element backed the younger brother. The Pharisees, on the other hand, not finding Hyrcanus to their heart, both in ability and disposition, and realizing also that the stmuggle would involve new wars, withdrew from the field, (27) and left Hyroanus to bargain for his terms. An agreement between the brothers was reached--Aristobolus to become king and Hyrcanus High Priest.

Hyroanus, in his monent of despair--for he was now ostranged from both parties--silently turned to a new group, an idumean-Jewish family, Antipater by name, who to saw in

(26) Marx and Margolis, History of Jewish People, p. 161.

(27) Halevi, Doros Harishonim 1, pp. 527-28. 
the younger prince a hindrance to his ambitions. Accordingly, they both fled the city and returned at the head of an arny. Aristobolus was defeated, retreated to the Temple and a siege followed. It was at this moment that a messenger appeared from rompey, who had been sent by kome to Asia, and ordered the raising of the siege. Both brothers were to appear before rompey in Damascus. When the deputations of the contestants arrived before the general, it was found that a third one had come from the people to ask for the abolition of royalty and a restoration of the old (28) theocratic constitution. It was a telling event: it showed that the people did not regard either of the two brothers as possible ideal rulers. Pompey reserved his deoision and meanrhile asked Aristobolus to accompany him on some Nabatean expedition. Aristobolus consented; but realizing that he was playing too easily into the hands of the Roman, and high-handed that he was, he fled at the first opportune moment to a fortress in ralestine. Forced to surrender, he managed to escape to Jerusalem. It was thither that rompoy retired, and took Jerusalem by force ( $63 \mathrm{B.C.})$. Aristobolus was taken captive to Rome and made to march in the procession of pompey's (28)

$$
\text { Moore, Judaism, i, p. } 72 \text {. }
$$


triumph, while Hyrcanus, a pawn in the hands of Antipater, was made Ethnarch.

There followed a twofold result out of this complication. The sadducees, having supported Aristobolus, came to be identified as an anti-Koman party; while the rharisees withdrew entirely, out of despair, from the political field and went back to their schools and theoretical studies. They became as a party indifferent to politics. Henceforth, the history of Judaea followed along the development of these two trends. Descendants of Aristobolus emerged time and again to regain the country by arms; but with every new attempt that was put down, the Antipater, proKoman, family ponetrated more deeply and harshly into the heart of the country and people. The nation became enfeebled to the last degree. Thus, when Antigonus, son of Aristobolus, seized the country, with the help of the rarthians, and managed to rule it for three years, Herod, son of Antipater, returned with koman legions and reconquered the land anew step by step. "1t was a war that drenched the land of 1 srael in blood." (29)

Herod's reign in Palestine was from its start therefore that of a foreign king. Lavishing money on many foreign

J. Klausner, Jesus of Nazareth, p. 143. 
Hellenistic cities to earn fame and honor, his rule in his own country was characterized by an attempt "of wiping out all memory of the Maccabean house and the noble families which supported it." ${ }^{(30)}$ He deeply mistrusted and bated the people. His mistrust went as far as his wife and his owm children, whom he killed off at the slightest suspicion of disloyalty to him. "jcarce a day passed but someone was put to death....Bloodshed, confiscation of property, harsh taxation, stern political oppression, deprivation of freedom, suspicion, espionage, flattery of the great, increase of want and poverty--these are the marks of Herod's government." His contempt for the people he ruled was great, but he suffered them, as long as they kept out of mischief and paid his taxes, to pursue their interests. The innocent tharisees he left unmolested; for "he could soe that the materials for a revolt lay ready to hand in the power of the tharisees over the mass of the people." (32)

For thirty-three years Herod reigned and exasperated the will of the people. Even the moderate Pharisees could hardly refrain from developing a deep aversion to existing

J. Klausner, Jesus of Nazareth, p. 145. Ibid., pp. 148-49.

Herford, The Pharisees, p. 49. 
conditions. For "as bad as the rule of the Hasmoneans had become, that of Herod was worse, and behind all was the possibility of far greater ills in the oncoming might of Rome." So when Herod died, delegates of the people once more appeared before the high tribunal of the Roman Empire, the Emperor's court, to plead in favor of home-rule directly subject to Rome itself. As their wish was not heoded, Herod's will was confirmed, and Archelaus, his son, was made Ethnarch. Ten new years of oppression followed, when Archelaus had to be recalled and banished to Gaul. Judaea sank into a Roman province administered by a procurator resident in Caesarea, and subject to the authority of the prefect of Syria.

Theoretically, the rule of the first group of procurators $(6-41$ A.D.) should have been an era of peace, and the Jewish people should have had no cause to complain for any want of consideration paid to them. The Jewish (34) religion stood under state protection; the Emperor worship, except in the time of Caligula, was not demanded in Palestine; the administration of civil law was in the hands of Jewish Courts. In practice, however, "the average (35)

Herford, The Pharisees, p. 49.

Schurer, History of Jewish People, $1^{2}$, p. 75 . 
Roman offloial was always disposed to disregard all such nice, delicate consideration. And the unfortunate thing was, that Judaea, especially in the last decades before the war, had more than one governor who had lost all sense of right and wrong." (35)

The last ray of hope appeared in the short reign of Agrippe I, a grandson of Herod, who was reinstituted as king of the whole of Palestine by Caligula, whose personal friend he was. The brief reign of three years came like a healing balsam to the suffering people. But upon his death that was sudden, Judaea once more became a Roman province to be administered by procurators, while his son Agrippa II was invested with only the small kingdom of Chalcis, in Northeastern Palestine, together with the office of supervision of the Temple, and its accompanying right of nominating the high priests.

The second group of procurators (44-66 A.D.) to whom the government of the country was now entrusted brought to a olimax the entire period. Their rapacity and severity simply drove the people to rebellion. "Even the best among them, to say nothing at all of the others who trampled right and law under foot, had no appreciation of the fact that a

(35) Schurer, History of Jewish People, $1 I^{2}$, p. 79.
(36) 1 bid., p. 157 .


people like the Jews required, in a permanent degree, consideration for their prejudices and peculiarities. Instead of exercising mildness and toleration, they had only applied themselves with inexorable strictness to suppress any movement of the popular life." "The rupture finally came during the administration of Florus. Moderate tharisees and Zealots rose in determination against the insistent insolenoe of the governor. Agrippa who was then at Alexandria hastened to Jerusalem and urged the people, in an open assembly, to abandon the hopeless struggle. The people were ready to establish order, and declare their allegiance to the emperor, but would not yield to reaccept Florus. As Agrippa, however, insisted even on the latter point, the Zealots carried the day by decreeing the suspension of the customary daily sacrifices brought for the Emperor. That was bold act, equivalent to an open declaration of war. Agrippa and his troops were routed, and the Roman garrison in Jerusalem subdued.

The advance of lestius Gallus from Syrla and his sudden unaccounted for retreat which onded in a flight, and a great victory for the Jews, gave the people further courage and hope in their firm decision of war. The last bridges were burned and the party of reconciliation ceased (37) Schurer, History of Jewl sh People, $1 I^{2}, p .167$. 
to exist completely. Judeea definitely entered into a life-or-death struggle.

The tragic consequences of the destruction were inevitable. The apportioning of the country into provinces and the appointment of generals for their defense--Josephus our historian receiving the district of Gelileo-would have under the best conditions of unity and efficiency only prolonged the struggle; the outcome was clear. As it was, group oppositions and petty personal calculations helped to speed the work of the enemy. "The Jews fought with all the despair and heroism born in the defence of home and religion against the insolent alien tyrant." (38) But it was of no avail. Significant of note, however, was the fact that the men who now had the power in their hands "belonged exclusively to the higher ranks. The chief priests, the most distinguished of the Pharisees, were those who directed the organization of the land defence."

The union of all classes of poople against Rome brings into relief the existence of a certain incompatibility between the Koman and Jewish elements of life that even the peaceful, non-politically minded, Pharisees were constrained to admit. We must turn to the nature of that incompatibility, (38)

Goodman, History of Jewish People, p. 35.

schurer, History of Jewish Feople, $I^{2}$, p. 214. 
in order to understand the restlessness of the entire period, which formed the immediate background of Josephus. (c) Incompatibility of Roman spirit and Jewish Life

"The Roman rule in Palestine is one of the tragedies (40)

of history." The nature of the antagonism between Roman and Jewish elements will forever remain a theme of interest. Rome had suoceeded in subjugating and pacifying all the Mediterranean nations; in the course of that process, it had used devastating warfare only for purposes of external conquest, but seldom for the internal submission of a people to its rule. For once a people acquiesced in its loss of political independence, and recognized the sovereignty of Rome in state matters, autonomy was granted in practically all cases, and the yoke of submission was not found to be too burdensome. In Judeea alone, the country, for the 130 years of koman rule, hardly ever submitted to the foreign yoke. Fires of revolt were always smouldering. A possbile hasis for harmony was never achieved. What were the causes operating in making Judeea the exception? Mere difference of religion could not apparently have been the cause, since the Jewish people of the second Commonwealth had repeatedly shown that they could cooperate with Yersians, Seleucian and Ptolemayan Greeks, though they did worship other gods. There (40)

F. Jackson, Josephus and Jews, p. 154. 
must have been therefore something more fundamental then mere difference of religion that hindered the development of a peaceful palestine under Roman rule. What were the causes?

In the list of these causes, prominence must first be given to the growing intense Jewish public consciousness of its religious heritage. The time when pure monotheism with its uncompromising standard of worship was championed by a few prophets alone was gone; a peculiar phenomenon had instead arisen. The entire people, speaking in terms of the bulk of the nation, came to be so imbued with religious teachings and conviotions that even martyrdom could not stand in the way of their attachment to them. In part, the rise of this religious consciousness was due to the hegemony the Pharisees wielded over the people, with their democratizing the eduartional institutions of religion, with their emphasis on personal piety and individual responsibility. But whatever the causes of this phenomenon were, it continued to be throughout this entire period a factor of tremendous significance. It accounts why a sacrilegious act of some Roman official immediately aroused the antagonism of the entire poople as of one person. The average Roman, or for that matter any pagan, hardly comprehended an uncompromising attachment of that 
kind of religion. To him, religion was binding, but with a looseness of standards. Polytheism in particular was never as demanding and exacting as strict Monotheism. In the eyes of the average koman, the ordinary Jew must have therefore appeared a senseless fanatio, sensitive of any question that even but slightly touched his religion, and void of appreciation of the arts and accepted standards of pagan Iife.

At times, the Romen might have been awed by the sincerity and deepness of the conviction the Jewish person entertained for his religion, but he could never tolerably understand him. Thus, the famous scene of the "standards" between Pllate and the people at caesarea; the latter had gotten wind of the faot that Pilate had placed roman standards with images of Caesar within Jerusalem, and immediately crowds hastened to laesarea to petition him to remove them. Josephus pictured the scene pointedly.

"pilate sat upon his tribunal, and called to him the multitude as desirous to give them an answer; and then gave a signal to the soldiers, that they should all at once encompass the Jews with their weapons; so the band of soldiers stood round about the Jews in three ranks. The Jews were under the utmost consternation at that 
unexpected sight. Pilate also said to them that they should be cut in pieces unless they would admit of Caesar's images, and gave intimation to the soldiers to draw their naked swords. Hereupon the Jews, as it were at one signal, fell down in vest numbers together, and exposed their necks bare, and cried out that they were soon ready to be slain than that their laws should be transgressed. Hereupon Pilate was greatly surprised at their prodigious superstition, and gave order that the ensigns should be presently carried out of Jerusalem." Pilate, humiliated and possibly awed must certainly have shrugged his shoulders at that display of fanaticism. It was to him a display of "prodigious superstition". H1s further experience with them, as their resentment of his using the funds of the Temple for the construction of an aqueduct, must have only driven him conclusively to the conviction that whatever was of Roman origin seemed to be distasteful to the Jews. That the cause of their opposition was religtous, and from their standpoint therefore justified,

Josephus, wars, ii, $9,3$.

Lbid., 11, 9, 4 . 
only brings into further relief the prominence of the intense religious consciousness as an element contributing to the discordance existing between Koman and Jewish life. The nature of the typioal Roman official of the period was another factor that hindered the development of an harmonious fusion of Roman and Jewish interests. At best, he regarded a province as an opportunity to become rich. He was generally poorly equipped to understand the nature of the people amidst whom he was sent, and he did not care to go out of his way to understand them. He was in the province to oarry out his duties--enforce peace, quiet seditions, see that taxes are paid, ete.,--and cared little for the ways and means by which he accomplished them. And why should any people, he must have thought, be given special privileges and allowed inmunities from certain duties that were expected of everyone in the Empire? He was therefore loath, and at times quite deliberately unwilling to pass over minor troublesome interests, which might have easily been aroided. Thus, he demanded that the Highpriestly robes be sealed and deposited with him, to be given over to the people only on festival seesons. "Ihis was a most galling insult to the people; a more marked symbol of subservience could scarcely be found." (43)

Klausner, Jesus of Nazareth, p. 161. 
A similarly minor but of fensive incident was the stationing of soldiers in the Temple during holidays to keep order--another flinohing insult to the people. The blessings the Romans brought to the country, as peace, roads, etc., were consequently forgotten in face of the public fear of the Roman's flouting his religion. Thus irritated and affronted, the rancour, hatred, and wrath of the people were slowly nourished, while the Roman in turn driven to extremity conoluded that since he could not govern the people, he would be driven to destroy them. Thus, a Roman captain put down an ordinary sedition by burning a city, onslaving its inhabitants, and crucifying some 2000 people. (44)

The third group, the Herodian family, might have through some well-meaning endeavor possessed the key to the conciliation between the Koman and Jew. But unfortunately, the Herodian group so completely identified itself with Romen policies and sympathies that the people always saw that their only hope of retaining peace in the country was that this group should not hold the reins of government.

(44) Josephus, Wars, ii, 5, 1-2. 
"How great must have been the sufferings endured by the people to make them see freodom rather in the rule of a foreign power than in the rule of one of their own faith." The chasm betweon Roman and Jew was thus left unbridged. How little the people could look upon the Herodiens for understanding and help is seen from the faot that when they finally plunged into the struggle against Rome, the Jewish-Herodian king, Agrippe II, joined with his army the Roman legions, and had a hand in the destruction of Jerusalem and Templo.

There could therefore be no harmonization between Roman and Jew as there had boen between Hellonism and Judaism. For in Hellenism the Jew saw a culture; there was a middle group that spanned the ultra Jewish and Hellenistic forms of life. In case of the Roman rule in Palestine, there was no such group. The Jew therefore saw in its rule nothing but the army. Arersion to its outward material and militaristio forms was bound to follow.

The incompatibility between Roman and Jew is thus clear. The lifo of Josephus, which in essence is an attempt of finding a harmony between these two opposing foroes becomes therefore of spoial interest to our greater problem of Josephus as a historian.

Klausner, Jesus of Nezareth, p. 154. 
B. Life of Josephus

The life of Josephus bears an outward resemblanoe to that of Thuoydides and Polybius. Like the former, he was a leader and eye-witness in the war of which ho afterwards became its historian, and like Polybius, the break between commander and author was oocasioned by a submission of the general to the Roman order of life. It follows that the life of Josephus is divided by the great war of his time into two portions, and as it happens, into two nearly equal portions: "Thirty-three stormy years spent in Palestine by the priest, patriot, general, and prisoner, Joseph ben Matthias, and a period of comparative calm passed by the Roman oitizen and man of letters, Flavius Josephus, in the capital of the Empire." (46)

\section{(a) in ralestino}

Josephus was born in the year 37 A. D., the first year of the reign of Caligula, to an illustrious priestly and aristocratio family in Jerusalem. On his father's side, he was a priest of the first of the 24 sacerdotal orders, and on his mother's side, he was of royal race, "since she was the daughter of Jonathan, the first of the Hasmoneans to rule over 1 srael in the capacity of High Priest".

Judaism and the Beginning of Christianity, art. "Josephus", p. 169 .

(47) Josephus, Life, 1

(48) ıbid., 1 
The early years of his life were spent in rather peaceful and tranquil times. A year before his birth Pontius rilate had been recalled, and Agrippa 1 given his liberty and kingdom. When he was seven years of age, and began coming in contact with the city environment, the period of the second group of procurators had set in. Perhaps the earliest impressions he retained were those of a pretending prophet, Thaddaeus, who when having gathered a multitude of people to the Jordan to perform there some miracle or act of baptism had been overtaken and killed by the first procurator Fagus, and his head, struck off, was carried into the city as a warning to the people. But in comparison with the turmoil and excitement that followed under the coming procurators, this period in Josephus' life was comparatively peaceful.

His education, as of all youths of his age, centered in the Torah and tradition. He was careful to inform his readers of his early accomplishments in that field.

"I made mighty proficiency in the improvements of my learning, and appeared to have both a great memory and understanding. Moreover, when 1 was a child, and about (49) Josephus, Antiquitios, xx, 5, 1 . 
fourteen years of age, I was commended by all for the love I had to loarning; on which account the high priests and principal men of the city came then frequently to me together, in order to know my opinion about the accurate understanding of points of the law." (50)

The account, as one author renarks, puts one over on Luke, who makes Jesus sit in the Temple as a disciple of the kabbis, while here the Rabbis go consulting Josephus - in his home. That the statement of the latter must not be taken on its face value oan be seen from his mature works, where Josephus does not by any means reflect a profound knowledge of the law and tradition of his people.

When he was sixteen, he resolved to study the tenets of the three sects of Judaism; accordingly, he applied himself to the great teachers of the time--Gamaliel the Elder, the great tharisaic leader, and Banus of the kissenes. As the latter resided in the wilderness, we are to trust Josephus that he attached himself to that sect for three years, in resignation of all the luxuries of the city. It is possible that here, living in the kissene community, he attained his belief and practice in those elements of superstitious (50)

Josephus, Life, 2 .

Jackson, Josephus and Jews, p. 6 .

see below pp. $63-64$ 
religion which so well coincided with Greco-koman belief, and which were of good advantage to him later on in life, namely, the prediction of future events, and the meaning and interpretations of dreams. At the age of nineteon he returned to Jerusalem, and decided to associate himself definitely with the rharisees. It was a prudent thing to do. Representing the paoiflst group, whioh affirmed belief in mortal as over against physical force, the tharisees as a whole were left unmolested by the Romans; and championing the whole tradition, the Pharisees had their influence orer the masses of the people. That Josephus was not sincere in his Pharisaic convictions, we shall later demonstrate. But nominally, and indeed for all practical purposes, he was then a priest and a rhariseo.

In the next six-seven years that he spent in Jerusalem, he must have had many opportunities to affirm his influence in many circles and on many occasions. The times were quickly becoming intensely nervous. The procuratorship of Felix, in itself an unheard of precedent--as he was practically the first freodman upon whom an of fice with military command (54)

had been conferred --had encouraged misgovermment in all directions. It was no wonder that bitter feeling against (53) Bentwich, Josephus, p. 41. Schurer, History of Jewish People, $\perp^{2}$, p. 175 . 
Rome was increasing. Then the Zealots attempted to rise, innumerable crucifixions and general punishments became the order of the day. As severity and cruelty gave occasion to still further trouble, the sioarii arose--a still more zealous group of the patriots. Armed with small daggers, they would mix among crowds and make short work of Romen sympathizers. When Felix was recalled and Festus sent in his place, an attempt was made to undo the mischief of the former procurator. But Festus died while scarcely holding office two years, and the coming of Albinus only intensified the conflict and hurried it on to its final bloody conclusion.

In all of these stirring events it was impossible for a priest and an aristocrat not to have his hand in things somehow. Thus, in the second year of the procuratorship of Albinus, 63 A. D., the trenty-sixth year of Josephus' life, he left his country on a voyage to the imperial city of Rome, to help the release of certain priests, closely related to him, who had been arrested for political suspicions by the governor felix and sent to Rome for trial. The royage could not have been without a lasting impression on our hero. Having left his country in a moment when it was seothing with turnoil, bitterness and confusion, he sailed into the peaceful western hemisphere of the Roman Empire. He was shipwrecked on the first boat in the Adriatic and had to swim for his Iife 
until sighting in the next morning a vyroene ship. The horrors of that night must have quickly faded out of his mind as he sailed on from there to puteoli, thence by road to the Rome of Nero times. Through a Jewish actor, Aliturius, a favorite with the famous roppea, Nero's wife, he was presented to court, and through her obtained the end of his mission, as well as many presents--"a fact whioh goes far to suggest that the young Jew was not deficient in good looks and courtly manners and well acquainted with the great art of flattering those who might be useful to him."

As he returned home, he took along with him, besides his friends and presents, a deeply-seated impression of the might an invincibility of the koman power. "The Imperial c1ty was then at the height of its material magnificence, and must have made an immense impression of power upon the young Jewish aristocrat." (58)

When Josephus stepped into Jerusalem the year 65 , things were beyond control of any one person. The outrages of Florus had just occurred, and the people had been driven

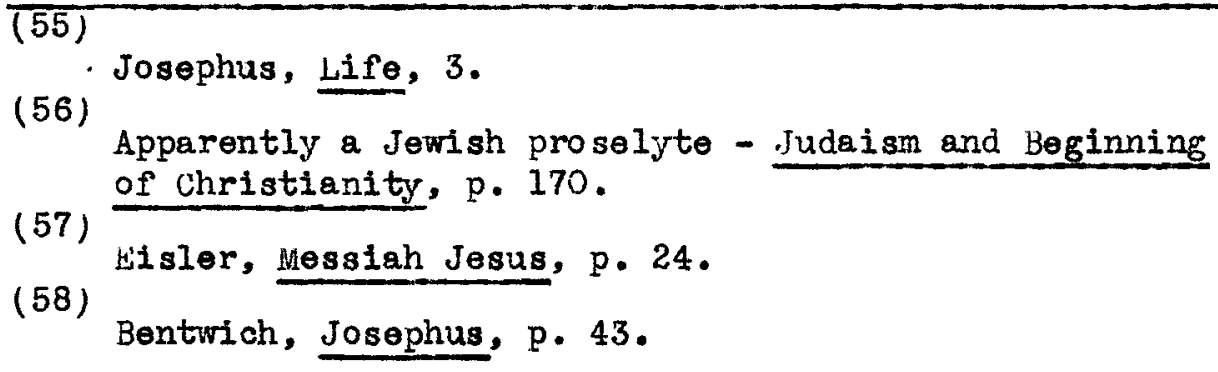


to despair. The Herodian party, i.e., the royal house and its supporters, endeavored to preserve peace by dwelling on the inevitable end of the insurrection--but it proved of no arail. There followed the march of vestius Gallus in the autumn of 66 , and his defeat at Betin-Horen, the massecre of the Roman garrison in the city--the war party had become dominant. Josephus was carried along by the rising stream of rebellion. Finally, when the sanhedrin turned into a council of war and apportioned the country into military districts for protections, Josephus was given his famous, or infamous, post of taking charge of Galilee. For the next six months, i.e., between the autumn of 66, and Vespasian's arrival in the spring of 67-everything in Josephus' life is shrouded in mystery. He himself gives us in his books, the Life and Wars, such two radically opposing aocounts of his plans and aotions during that period that hardly anything definite can be seen. To mention one of the many disorepancies: in the firars, he is sent as one of the six generals to conduot a regular campaign, and in the Life ${ }^{(60)}$ on a pacific mission to disarm the Galillean insurgents. Modern Josephan students, however, (59) (60) Josephus, Wars, ii, 20,3 . Josephus, Life, 7. 
have reconstructed the account in its major points:

1. Josephus, hardly thirty years of age, had very little to commend him for that most responsible military (61)

post of all, save the influence of his distinguished

friends in the upper circles. Now these friends had by force of circumstances gone over to the war party, but still silently retained hopes for poace, and awaited the coming of a new roman army to dishearten the rebellion. Josephus while accepting the commend for war was yet to go and procrastinate things until the komans would come. His policy was thus from the start a double waiting game.

"Une is fain to surmise that those who sent him, as well as he himself, were anxious to pretend resistance to home, but really to work for resistance to the rebellion."

2. Then Josephus came to Galileo, he found the people almost violently ready for war, save one city, Sepphoris. 'the Galillean people, in constant insurrection for the last half contury, had been the most sturdy and warlike element of the country; it was there that the

Schurer, Hi story of Jewish People, $\perp^{2}$, p. 215.

H. Thackeray, Josephus the Man and Historian, p. 12 . Bentwich, Josephus, p. 46. 
Zealots and Sicarii first arose. Hach town particularly had its popular leader. When the poople observed the ambiguous acts of Josephus they began to suspect his intentions and, finally, accused him openly of doubledealing. Things oame to an is sue when Josephus prevented John Gischala, a popular leader, from seizing imperial corn stored in the province, and further declared his intention of returning spoils seized from the stewrard of King Agrippa, already the avouched enemy of his people. Intrigue and mutual atternts of assassination followed, and the citios arose against the leadership of Josephus. His conduct was reported to Jerusalem. When a deputation was sent to investigate the matter, he, warned by his friends of their coming, seized them--and recaptured the cities that had been in revolt against him.

3. Meanwhile, the winter passed, and in the early spring, Vospasian in all sincerity moved down upon Galilee from Syria. The dissenting oities, together with Josephus, were constrained to do something about proteotion. Josephus at the first sight of the koman legions lost heart and immediately retreated into the fortress of Jotapata. There he held out a forty-seven days siege, when on the taking of (64)

Schurer, History of Jewish People, $\perp^{2}$, p.217. 
the fortress, he and other leaders took refuge in a cave. Discovered, Josephus wanted to surrender but was prevented by his companions, who decided that all should rather die by the hands of one another than surrender to the Romans. By plain cheating in the casting of the lots, (65) he was the last one to survive, and then surrendered to a koman officer, Nicanor, an old acquaintance. "How he had come to make such useful acquaintances in the enemy's camp, he is careful not to tell."

From then on his progress was rapid. Brought before Vespasian, he resorted to uttering something which though it had been for some time in the air was yet dangerous to voice. But the miracle worked: he told Vespasian of a prophetic dream concerning his rise to the imperial throne. The Koman general was quietly impressed, and at the suggestion of Titus spared meanwhile Josephus' life. The coning year of 68-69, the year of the four emperors, showed Vespasian that Josephus' prophecy was right. He was then given his liberty and made to accompany Vespesian to Alexandria. From there, he returned with Titus to the siege of Jeruselem and together with Agrippa 11 fought against his countrymen.

Eisler, Hessiah Jesus, p. 199

$$
\text { ıbid., p. } 25 .
$$


In particular, his task was to deliver orations, within the hearing distance of the people on the walls of the city, to desist them from their struggle against Rome, and convince them of the invincibility of its arms. His words had no effect. Coming as they did from the mouth of a traitor, his words made only some faint-hearted persons desert; the multitude received them with scorn, and pressed on the siege more vigorously than ever. The end came in the summer of the year 70 when the city was destroyed and the Temple burned. Josephus was made to accompany Titus on his way through Syria to Rome--where there begen for him the second period of his life.

\section{(b) Life in Rome: His Works}

In Rome, Josephus quickly, and almost completely, pessed out from the life of his people. It is true that he professed to the end of his days allegiance to the Jewish religion, but the remarkable apathy with which he describes the glory of the triumph of the two Flavians, father and son-a triumph whioh marked the ruin of his country and people-shows Josephus to have traveled far away from the consciousness of his countrymen. It appears also very unlikely that he ever came in contact with his compatriots of that city. In Rome, there had always been, since the days of Pompey, an Important Jewish community. A part of the great Jewish Iife in the Diaspora of the Roman Empire, that group too was. 
imbued with all the qualities that marked the oharacter of such communities: zealous of its faith, missionary in endeavor, and extremely loyal to their nation and country. Josephus, traitor as he appeared to them, must have been an object of contempt in their eyes. The satisfaction of the imperial family with him--for he was now lodged in the royal palace, pensioned, and commissioned to write the triumph of the Flavians-must have only furthered the gulf between him and the Jewish people of Rome. With what inner equanimity Josephus spent these 35 years of his life, we are thus left to conjecture.

The intellectual cirole of Rome at this timo wes that of Pliny, Tacitus, Juvenal, etc. But Josephus was hardly of their group. The fashionable Greak tongue of the time he never mastered; he himself admits it. (67) His recourse in friendship was hence to his old acquaintance Agrippa II. It was he that kept in touch with Josephus throughout the period of his writing, and confirmed his (68)

books in 62 letters. That friendship, in itself an indication of the meagerness of Josephus' compansionship in Rome, is still from another angle, as we shall later see, (67) (68)

Josephus, Antiquities, $\mathrm{xx}, 11,2$. Josephus, Life, 65. 
hardly a flattery to the worth of our historian.

The first draft of "The Jewish Wars", written in Aramaic, and intended for Jews and Parthians of the East "to serve them as a manifesto of the futility of further opposition" (69) shows the last trace of Josephus' definite connection with his people. That was in the early years of his stey in Rome--perhaps as early as $72 \mathrm{~A} . \mathrm{D}$.

With his final Greek edition of the same work, our historian completely turned to the Greco-Roman world. Henceforth, his task was to color the history and culture of his people in Hellenized forms.

The Greek edition, though termed by Josephus himself as a "translation" of his earlier Aranaic version, (71) is, however, in its present form of no such nature. "A remarkable fact about it is the purity of the Greek and the entire absence of any sign of its Semitic parentage."

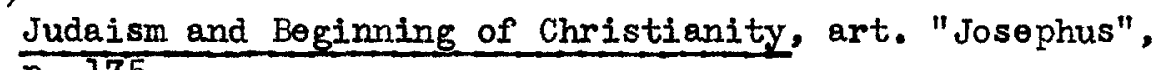
(71) 
It appeared towards the end of Vespasian's reign--between the years of 75 and 79 A. D.--and immediately received official commendation of Titus and a copy was ordered to be placed in the Imperial library.

The death of Titus in 81 shook somewhat the position of Josephus, partioularly his royal pension. Domitian was no patron of literature; and though he went to the extent of punishing the enemies of Josephus for having falsely accused him of offering suocor and help to a Jewioh Zealot rising in Cyrene, end also made his property in Judaea (73)

exerpt from taxes, he yet showed a dislike for all poets and historians. Josephus, though still finding a constant benefactress in the Emperor's wife, Domitia, was to a great extent thrown back upon his own resouroes. He now severed his relations with Roman political propoganda (74) and entered upon historical work of relatively individual enterprise. His life from now on became still more destitute of friends.

Thus, Josephus, in the quiet years of the maturity of his life, turned to his "magnum opus", the Jewish Antiquities, the narration of Jewish history from its beginning until the outbreak of the last war with Rome.

F. Jackson, Josephus and Jews, p. 18.

H. Thackeray, Josephus the Man and Historian, p. 52 . 
It was a long and tedious task; and during the twenty years it occupied the author's attention, he had a number of times placed it aside and returned to it. The work had its genesis in the writing of his Wars when he commenced prefacing it with a short sketch of Jewish anteceding history, and then realized that the latter must form an independent work in itsolf. The Antiquities appeared in parts, and was modeled after the koman Antiquities of Dionysius of Halicarnassus. It was Josephus' ambition to become not only the classical author of his people's history, but also that his work should be a counterpart to vionysius' Antiquities. His abiding friend and inspiration during this period was a certain Epaphroditus, a celebrated Honeric scholar and librarian, to whom he dedicated his Antiquities. The work appeared in the year 94 A. A.--i.e., towards the end of (76)

Domitian's reign. It marked Josephus' attempt of shaking off the Roman fetters of his mental servility. But it was only an attempt. Soon there transpired something which forced Josephus into the most malevolent blackening of his own character. A rival Jewish historian, Justus of Tiberius, had published a history of the wars in which he accused Josephus of having caused his native city to (75) (76)

H. Thackeray, Josephus the Wen and Historian, p. 56. Lbid., p. 15. 
rebel against Rome. The accusation almost endangered Josephus' security at Rome. He was consequently bound to retort. The result was his Life, really an appendix to a late edition of the Antiquities. In that autobiography, which by reason of its genesis concentrated on the six-month period of his suspected military activity in Palestine, he openly avowed that his military polioy from the beginning was to betray his province to the komans. It was hardly a thing to do in consonance with a man of honor. But to Josephus apparently protection and peace in his old age-for he was now over 60--were objects to be more cherished than the remorse of a stricken conscience. The Life must have been written shortly after the year 100 A. D., as it alludes to the death of Agrippa, which we know to have ocourred at that time. (78)

There followed in quick succession the last, and perhaps the most attractive, work from the pen of Josephus-Against Apion. It was not an historical work but a defence of his faith against pagan and general calumnies of the first century against the Jewish religion and people. It was the one redeeming passion in Josephus' life: "In the defense of the Jewish Law we have the true Josephus, driven in his old (77) (78) Life, 13, 35, and entire tone of the work. Thackeray, Josephus the Historian, p. I6. 
age by the goading of enemies to throw off the mask of Greco-Roman culture, and standing out boldly as a lover

of his people and his people's law." The work exhibits great literary skill and a wide acquaintance with Greek literature.

These two last short works are of particular interest in that they manifest the presence of a duality of forces in Josephus' character: the Romanized Josephus of the Life and the Jewish patriotic Josephus of the Apion.

The exact year of his death is not known, but it is generally conjectured that he lived to see the early reign of Trajan. (80)

\section{Character}

with an eventful and suspicious life of that kind, it is no wonder that the character of Josephus is open to many interpretation. He has called forth enthusiasm on the part of nobody. It is only in the nature and degree of condemnation that the interpretations differ. Generally, . there are three divergent views taken of his character.

1. Eisler conceives Josephus to have been consciously and deliberately perverse in his actions, an opportunist of the worst kind, always pursuing his own schemes, changing and deleting passages in his narratives which would prove

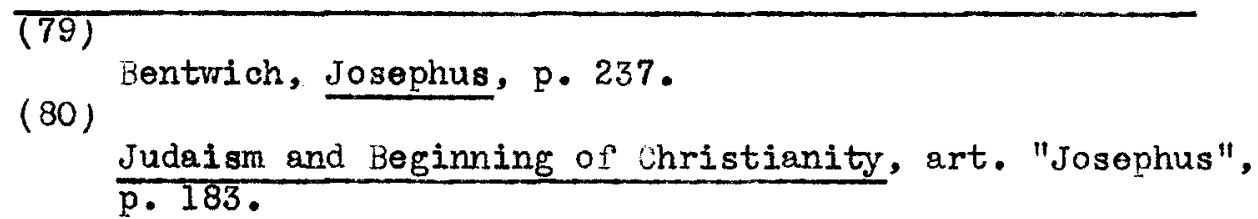


distasteful to his influential readers, or would reflect on him personally anything which might endanger his safety with his patrons. It is the picture of a Josephus thoroughly a parasite with not a single redeeming quality. "A characterless individual"...." wrotched renegade"..." most anxious to whitewash himself and attribute the blame for everything to the insurgents"...."his account is the typical spectacle of the swindler giving three different accounts to the police, to the prosecuting attorney, and at the trial." (81)

2. A contrasting quite charitable view of his character is upheld by other students. It is claimed that his early life and activity in palestine were those of any honest and loyal patriot of his people. The various attacks of his enemies were indeed all besed on the contention that Josephus in Palestine was one of the instigators of the war against Rome. When, however, he surrendered into the hands of the enemy, self-preservation dictated that he blacken his own character as a Jewish patriot in order to save his skin. In that case, we behold a character at bottom sound, devoted to loyalties, but circumstances forcing it to be guised under a protective covering which was not

Eisler, Messiah Jesus, p. 196.

Thaokeray, Josephus the Man and Historian, p. 19, and Bentwi ch, Josephus, p. 55 . 
of its pure essence. As quickly therefore as conditions permitted, or when goaded on to an unbearable position--the true Josephus appeared. Even in times of his Roman pretentions, he always managed in his writings to allude somehow to the loyalties of his convictions. Thus it is pointed out that in the concluding chapters of the Wars, written when the saviors to whom he owed his life and freedom were still alive, he finishes with an outburst of patriotism in name of one of the Jewish Zealot generals who had been the last to hold out against Titus. "Yerhaps he had denounced the Zealots throughout the history perforce, to please his taskmasters, and in his heart envied the party that had preferred death to surrender."

3. The moderate and most plausible view of his character sees in Josephus the struggle of two elements-the Roman and the Jewish--and a general oscillating between its two extremes. Priest that he was, it was inevitable that Josephus should not have a deeply-seated pride for his people and its culture; and aristocrat that he was, and nearer therefore to the Roman life than the ordinary Jew, a sense of deep respect for the Roman could not again have escaped him. Torm between these two extremes, he had a further incapacity--the inability to be the master of his own (83)

Bentwich, Josephus, p. 134. 
convictions. His visit to the imperial city certainly swang the scale in favor of the Roman side, but in practical life he was immediately bound to identify himself with its opposing side. For upon his return to Jerusalem, he was swept along by the massive wave of the insurgents, though in his heart of hearts he retained at the same time a doubt as to his people's superiority. He was dazzled by the brilliance of the Roman army in march. Watching it from the walls of Jotapata, he was awe-stricken by its impressive manoeuvres. He saw he was on the wrong side, but dared not speak out his sentiments. Finally, when he surrendered and saw the ruin of his country and friends and was in safety already on the Roman side, pensioned and respected, he yet hearked back to his origins. Face to face with the external splendor of home, its dissolute and licentious life in the capital, the Hebrew in him awakened. The Antiquities he composed were inspired by that genuine motive-of holding up to a pagan world the meaning and greatness of the history of his people.

But the new resolution was only in his library. in actual lif'e, he was to experience once more the helplessness of his own infirmness. For as soon as he was attacked, he (84) Life, 35 . 
lacked the strength of standing up to the test of his convictions. He was therefore compelled to restate, even in firm affirmations his Roman sympathies and leanings. But as that performance did not give him full satisfaction, for the Jew in him after all too demanded a more powerful expression, the Apion was the result. And so he died a broken man--a victim of his conflicting environments. In his quiet moments, Josephus may have thought that he had attained a harmony of the Roman and Jewish elements in his personality. For that certainly was his pride and the nature of his claim to become the historian of his people. but it is after all not in the quiet moments that the mettle of an idea is tested. The moments of crisis do that. And when these came, Josephus appeared in character as a dual, broken man.

"He was, like Jerusalem herself in that day, between the Jewish and Roman powers." (85) the Wars, p. vii. 
II. POINTS OF THESIS 
1I. POLNTS OF TAESLS

The foregoing discussion must have illustrated the point that as an historian, Josephus cannot be taken on his face value. He was too deeply steeped in his environment to have been able to rise above it. He had too much at stake to tell the truth. In this general conclusion, all Josephan students agree. There, however, does the line of demarcation begin? At what point should the line of measurement be dropped to differentiate between truth and fiction, sound judgment and prejudiced condemnation, in Josephus' writings? As there are no great extraneous sources to check up on Josephus, shall we then say that since he himself is untrustworthy we must therefore abandon all hope of successfully re-establishing the centuries of his theme? It is part of the general purpose of this paper to advance three points which may be of some value in answering these important questions.

In the first place, it can be proven that Josephus though not trustworthy in his judgments is yet reliable in his facts. In other words, Josephus' perversion of his accounts went only as far as motives and interests, but not as to the facts themselves. The bottom facts of his narratives extracted, all they need is a re-interpretation to stand up 
in their true light. But where shall wo got these motives for that new interpretation?

It is the second contention of the paper that these new perspectives can largely be found through a careful search in the body of Josephus' text itself. These may be referred to as "slips", which though of a minor nature yet when examined really yield that new insight. In fact, it can be shown that these "slips" occur practically at all the great turning points of his history.

Thirdly, it may be shown that this new interpretation will largely be accelerated by accepting the position that Josephus was not, as ho claimed and as is usually accepted, a Pharisee, but that he was an anti-rhariseo in actions, beliefs, and sympathies.

A. B. Hacts and Judgments. "Slips"

We will consider the first two points simultaneously. 1. When Herod was returning from Rome, and with the help of the koman legions was establishing his kingdom by force, fighting the people at every step he advanced, the account in Josephus presents a struggle of unruly "cave robbers" against the advance of the enlightened Herod. The cause of the bitterness of that struggle is left

$$
\text { Josephus, wars, i, 16, } 2 \text { and } 4 \text {. }
$$


unexplained, and the significance of the Jewish resistance dwindles down to an ordinary struggle of anarchy against order.

"After which he (Herod) hastened away to the robbers that were in the caves, who overran a great part of the country, and did as great mischief to its inhabitants as a war itself could have done."

That these people, however, were no ordinary robbers is proven from the immediately following account, where Herod was proclaiming to "the cave robbers" amnesty if they would come up and deliver themselves to him, yet not one of them did it willingly, "and of those that were compelled to come many preferred death to captivity." (88) so we learn that these people were not ordinary bandits but fighting against "captivity", and for what they believed to be their liberty. But still the account is not entirely clear. who were these people, and why did they resent so bitterly his offer of pardon? There occurs the following description, a rather bloody incident, in which there appear a fow words that may throw light on that entire chapter in the history of that period.

Josephus, flars, i, 16, 2 and 4 . Lbid., i, 16, 4 . 
"A certain old man, the father of seven children, whose children, together with their mother, desired him to give them leave to go out, upon the assurance and right hand that was offered them, slew them after the following manner: He ordered every one of them to go out, while he stood himself at the cave's mouth, and slew that son of his perpetually who went out. Herod was near enough to see this sight, and his bowels of compassion were moved at it, and he stretched out his right hand to the old man, and besought him to spare his children; yet did not he relent at all upon what he said, but over and above reproached Herod on the lowness of his descent, and slew his wife as well as his children." (89)

The few words $\perp$ have underlined, $\perp$ think, may tell the story. The conquest of ralestine by Herod at this time was the advance of a foreign dymastic house against the legitimate house of the Hasmoneans. In the stand of the people against Herod, it was a conscious last rally of Lsrael against the encroaching ldumean supported by Roman arms. It is no wonder that the rally-point of Jewish arms in that moment was Antigonus, the last of the Jewish princely house. The struggle was further intensified by the hatred the people bore to Herod, a semi-barbarian, a foreigner and of "low (89) Josephus, Wars, i, $16,4$. 
descent", a usurper--an upstart of slave origin.

The "robbers in the caves" then were Jewish patriots who fully understood the import of Herod's advance.

2. The much-debated question of the nature of the three perties of the Jewish people of this period receives (90)

quite important consideration in Josephus' works.

But his account is neither consistent nor proportionately emphasized. The rharisees at times are pictured almost as darkly as in the pages of the Gospels. Thus, in speaking of the reign of Alexandra, he describes them as cunning and deceitful creatures:

"These tharisees artfully insinuated themselves into her favour by little and little, and became themselves the real administrators of the public affairs; they banished and reduced whom they pleased; they bound and loosed (men) at their pleasure, and to say all at once they had the enjoyment of the royal authority, whilst the expenses and the difficulties of it belonged to Alexandra."

That the reign of Alexandra with her Pharisaic ministers was not so disastrous as it might have appeared from this passage can be seen from parallel accounts of the same reign in other places of Josephus' history.

Josephus, Wars, i1, 8, 14; Antiquities, xili, 5, 9; xiii, $10, \overline{5 ; x i 1 i, ~ 10,6 ; ~ x v i i, 2, ~ 4 ; ~ x v i i i, ~ 1, ~ 2-3-4 ; ~}$ $\mathrm{xx}, 9,1$; Life, 2,38 .

(91) Wars, i, 5, 2.

(92) Antiquities, xiil, chap. 16. 
The general impression that one gathers fram Josephus on the sects is one of mechanical, doctrinarrian differenoe. "Whether souls die with the bodies or remain (93)

incorruptible"; "whether fate cooperate in every action, whether there is punishment and reward in Hades" $"$ (94) are the issues of their conflicts. Now while it is true that these differences were all there, nothing would be more erroneous than to place the emphasis of the divisions on these theoretioal questions. They are to be considered as consequences rather than as origins of the struggle of the parties. It is when we carefully examine some minor remarks of Josephus on the sects, and develop to a maximum point their meaning and significance that we may commence to see the parties in their true light. Thus consider the following short conments, occurring amidst lengthy and irrelevant descriptions of the sects.

"The Pharisees are affectionate to each other and cultivate harmonious relations with the community. The Sadducees, on the contrary, are, even among themselves, rather boorish in their behaviour, and in their intercourse with their poers are as rude as to aliens."

(93) Wars, xviii, 1, 4
(94) Wars, ii, 8, 14.
(95) Nars, ii, 8, 14.


"This doctrine (of the Sadducees) is received but by a few, yet by those still of the greatest dignity. But they are able to do almost nothing of themselves; for when they become magistrates, as they are unwillingly and by force sometimes obliged to be, they addict themselves to the notions of the Pharisees, because the multitide would not otherwise hear them." (96)

"The Pharisees have delivered to the people a great many observances by succession fram their fathers, which are not written in the laws of iloses; and for that reason it is that the Sadducees reject them and say that we are to esteem those observances to be obligatory which are in the written word, but are not to observe what are derived from the tradition of our forefathers."

"And indeed the Pharisees, even upon other oocasions, (98)

are not apt to be severe in punishments."

"The sadducees are very rigid in judging offenders, (99) above all the rest of the Jews." "There were two men of learning in the city (Jemusalem), who were thought the most

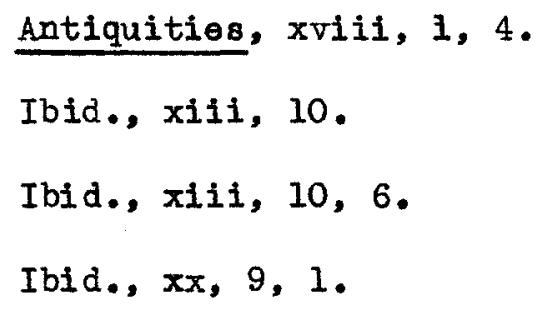


skillful in the laws of their country, and were on that account held in very great esteem all over the nation; they were, the one Judas, the son of Sephoris, and the other Matthias, the son of Margalus. There was a great concourse of the young men to these men, when they expounded the laws, and there got together every day a kind of an army of such as were growing up to be men."

From these scattered brief remarks, it is fairly easy to reconstruct the vital issues of party divisions. The democratic nature of the Pharisees, their influenoe over the people and particularly the young, their acceptance of the Oral Tradition, and their tendency of mitigating the harshness of the literalness of the law; and, on the other hand, the exclusiveness of the Sadducean group, with its insistance on an immutable law--those aspects may all be seon here quite distinctly. Developed in the light of their full import, they will yield the secial, economic, and political forces behind the famous socts.

3. The nature of the Jewish last struggle with Rome is another important theme that may be illumined by a careful analysis of Josephus' account. Gonorally, it is assumed that the struggle was one solely directed against Roman authority; that, however, in its origin, it was a (10)

Wars, 1, 33, 2 . 
rise against the Jewish aristocracy itself--the Herodian princess, as exemplified by Agrippa II, and high priests-is $11 t t l e$ suspected. But Josephus betrays the point here and there by a few words, and by checking up minor differences in parallel accounts, it is possible to see the course of events in that new light.

The High Priests of the period preceding the last war were nothing short of high-handed robbers.

"Aind now Jesus, the son of Gamaliel, became the sucoessor of Jesus, the som of Demneus, in the high priesthood, which the king had taken from the other; on which account a sedition arose between the high priests, with regard to one another; for they got together bodies of the boldest sort of the people, and frequently came, from reproaches, to the throwing of stones at each other.... costobarus also, and saulus, did themselves get together a multitude of wicked wretches, and this because they were of the royal family; and so they obtained favour among them, because of their kindred to Agrippa; but still they used violence with the people, and were very ready to plunder those that were weaker than themselves. And from that time it principally came to pass that our city greatly disordered." (101)

$$
\text { Antiquities, } x x, 9,3 \text {. }
$$


They were in a way even responsible for turning Roman officials of the country against the people.

"He (one of the high priests) cultivated the friendship of Albinus by making him presents; he also had servants... who joined themselves to the boldest sort of the people, and went to the thrashing-floors, and took away the tithes that belonged to the priests by violence, and did not refrain from beating such as would not give these tithes to them." (102)

The severity of the Herodians too is indicated. In particular, it was Agrippa 11 himself, who was to a great extent responsible for this state of anarchy. His income being derived chiefly fran the stewardship of the Temple, and his right of appointing the high priests, it was natural for him to bargain with his office, in all possible ways of advantage to him, without regard to the opinion of the people.

It is in that light that we may understand the vital meaning of a little episode told of Agrippa. He had raised a tower to overlook from his palace the services in the Temple, when the people, dissatisfied with his action, (102) (103) Antiquities, $\pi x, 9,2$. Nars, $i i, 14,1$. 
caused the building of a higher wall to intercept his view. A modern author beholds the incident amusingly. "Agrippa was wont to occupy the house that had formerly been the palace of the Asmoneans. This building, lofty even in its original form, he caused to be considerably heightened by the addition of a tower, in order that from it he might overlook the citadel and the temple, and to observe in his idle hours the secred proceedings in the temple. This lazy onlooker was obnoxious to the priests, and they thwarted his scheme by building a high wall to shut off his view. Agrippe then applied for assistance to his friend, the procurator festus, and he was very willing to give him any help he could. But a Jewish deputation which went on its ow authority about the business to Rome, managed....to obtain permission to keep up the wall, so that Agrippa was obliged forthwith to abandon his favourite diversion." (104)

In reality, the event may appear to have been more than a mere whim of desire on part of Agrippa to overlook the services. It may reasonably be assumed that it was an act designated to show the poople his authority in Temple affairs, and to keop them in chock. That Agrippa had no closer sympathies for his people than the ordinary (104)

Schurer, H1story of Jewish reople, $\perp^{2}$, p. 197. 
Romen governor will be proven later on.

The beginning of the war may have therefore been di rected against the high-handed ways of Agrippa and his associates as well as against the severity of the governors. This view is clearly alluded to by Josephus.

"Agrippa was equally solicitous for those that were revolting and for those against whom the war was to be made, and was desirous to preserve the Jews for Romans and the temple and metropolis for the Jews; he was also sensible that it was not for his own advantage that the disturbances should proceod." (106)

Agrippa's regard here for the welfare for the Jewish poople may easily be dismissed as a stock phrase of Josephus' oratorieal style; it was his own interests that Agrippa felt.

4. A final slip that want to consider is one concerning the nature of Josephus' own activity in Galilee. He tells us in one place (107) that the city of sepphoris rejoiced over the coming of cestius Gallus because it was pro-koman, and in fact throughout the war remeined on the koman side; while later on, (108) we are to believe him that the reason why he permitted sepphoris, alone of all cities, (105)

see below p. 94
(106) fars, ii, 17, 4.
(107) tbid., ii, 18, 11.
(108) tbid., ii, 20, 6.


to build a wall was because he was convinced of its readiness to go to war against the Romans.

"As to those of sepphoris, they were the only people to whom he gave leave to build their own walls, and this because he perceived they were rich and wealthy, and ready to go to war, without standing in noed of any injunctions for that purpose." (109)

Does not this minor example indicate how Josephus betrays his own true motives? Accepting the facts--that sepphoris remained pro-Roman, and that he gave it permission to defend itself by building a wall-we may definitely say that the reason for the second act was that Josephus in his entire period of actirity in Galileo wes betraying the cause for which he was sent; the building of the wall of Sepphoris was only for the protection of the city against the rebellious Gallilleans.

We may consequently see how a close reading of Josephus' narrative yields material with which to reconstruct the most importunt events of his history. c. Josephus not a tharisee

The final third contention is somewhat more difficult to establish, but appears plausible nevertheless from the following considerations. (109) ivars, ii, $20,6$. 
It is true that Josephus himself in his Life claims that early in his youth he definitely associated himself with the Pharisees; (110) furthermore, his history seems to be charaoterized by an application of Pharisaic doctrines to practical examples of history. Thus, he was always careful to accentuate lessons of reward and punishment in history, intercession of rrovidence in human events, etc. larefully examined, however, all these pious phrases appear as a mock-rharisaism.

In the first place, true tharisaism meant an abiding love and attachment to the Jewish people. No picture in Jewish history is as soul-stirring as the restoration work of the rharisees after the tremendous catastrophe of the Destruction. Originally counselling the people to abstain from fateful war, they yet remained with them at every step. And "when the storm died away, the tharisees alone survived... they were the only guides and teachers who had a word for the people; and they, and none others, saved from the ruin of the Jewish nation all that could be saved, and spoke to the stricken hearts of their countrymen the words of comfort and hope." (111) Jewish tradition is full with the heroic activity of the tharisees of the restoration period. Life, 2. Herford, The Pharisees, p. 52 . 
What a contrasting picture of contempt and disgust does Josephus present of himself in his works: seated in comfort and leisure in the palace of the enemy of his people he proceeded to paur out loathsome and unbelievable calumnies on Jerusalem and its leaders, and then justifled complacently the destruction.

" 1 believe that, had the Romans delayed to punish these reprobates, either the earth would have opened and swallowed up the city, or it would have been swept away by a flood, or have tasted anew the thunderbolts of the land of Sodom. For it produced a generation far more godless than the victims of those visitations."

Josephus, when he preached to the people during the siege of Jerusalen must have undoubtedly regarded himself as a Jeremiah or kizekiel, whose positions during the first Destruction were identical. And many scholars do indeed look upon them in a similar light. But one cannot fail to notice the great difference between them. Jeremiah when afterwards pardoned by the Babylonian king for his preaching of submission voluntarily assumed his captivity so as not to be separated from his people, while Josephus wanted to assume the robe of the prophet without paying his

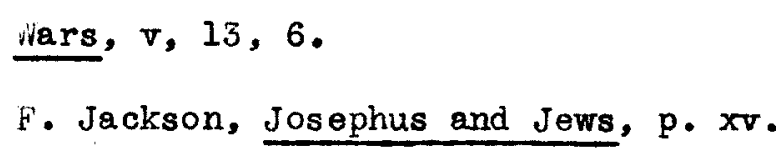


price. He was hardly an ordinary tharisee.

"It may, I think, be fairly inferred that Josephus, like most of the aristocratic priesthood to which he belonged, had little interest in religion for its own sake, and that his natural antipathy to all excess of zeal was deepened by the catastrophe which religious fanatics had brought upon his people."

The fact that Josephus believed in the Immortality of the soul, a Pharisaic doctrine, is not sufficient evidence to prove his allegiance to that party. Herod's brother, theroris, also affirmed his belief in that (115)

doctrine. Certainly, one would hardly conceive of him as being a tharisee. The truth of the matter is that the inmortality belief was widespread in the Greco-Roman world. It was only the sadducean party with its strict adherence to the written word that made it deny this doctrine. Otherwise, immortality of the soul was a generally accepted belief.

Josephus' claim to a knowledge of Pharisaic law was mere boasting. There are glaring mistakes of elementary law in his works that cannot be due to mere oversight. It is surprising that even his knowledge of the laws regulating the priesthood, of which he was a member, seems (114)

$$
\begin{aligned}
& \text { Moore, Judaism, i, p. } 210 . \\
& \text { Nars, i, } 30,6 .
\end{aligned}
$$


meagre. Thus, in describing the elght special robes of the high priests--the mitre, ephod, etc.--he informs us that these gold-embroidered robes were used only once a year on the Day of Atonement when the high priest entered the Holy of Holies. (116) Any one that knows anything of Pharisaic law will recall that the robes used on the Day of Atonement were only four, and of plain linen, and not the eight gold-embroidered ones. (117)

In fact, Josephus committed himself to quite an important statement in regard to one of the three sects which may perhaps be taken as a personal confession. In speaking in detail of the Essenes, their manner of life and beliefs, he rays: "These are the divine doctrines of the Essens about the soul, which lay an unaroidable bait for such as have once had a taste of their philosophy." But it is after all Josephus himself who once studied them. The mystic doctrines of the kssenes must therefore have left quite an indelible mark on his thoughts; his weakness for prophesying was a result of this training. Josephus though calling himself a tharisee was consequently far from having a knowledge or personal conviction in its

$$
\begin{aligned}
& \text { Wars, v, 5, 6. } \\
& \text { Mishna Yoma, } 3,6 . \\
& \text { Wars, ii, 8, 11. }
\end{aligned}
$$


principles. Whatever the positive content of his religion may have been, it certainly cannot be described as having been Pharisaic.

The results of this third contention may explain why Josephus is a smewhat disappointing source of the religion of his time. "1t is a striking fact that, if we were dependent on the works of Josephus alone, we should know very little about the religion of his contemporaries. In illustration it may be noted that of so important an institution as the symagogue there is no mention." (119) secondly, it gives us a general indication as to what we should expect to find in his principles of historiography. We will not meet a "Jewish" historian, but an historian of Jewish history. 
III. PRINCIPLES OF HISTORIOGRAPHY 


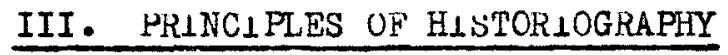

What we have seen to be true of the life of Josephus, namely, that its limitations went deop down into contemporary conditions, was equally true of the nature, form, and content of his works. Josephus was not original either in the content or in the form of his project. He stood as one in whom various historical trends and motives have converged rather than one from whom they have disseminated. He harmonized the content of a great period of Jewish historians that have preceded him with a form that was perfected by Greek and Roman authors .

We will 1solate all these factors into their respective positions.

\section{A. Sources}

The most conspicuous problem that presents itself in an analysis of the principles of historiography of Josephus is the nature and extent of the sources he used. A history extending over a period of two thousand years could not naturally have been a single man's achievement. Its author was bound to be dependent on the results of similar efforts of people that preceded him. How who exactly were these historians, and what was the nature of their endeavor? 


\section{(a) General Pre-Josephan Sources}

What the Persian wars did to Athens, the SyrianGreek Wars of the cocabees did for Judaea. The freedom attained from the oppressive heathen or barbarian occasioned in both countries an outburst of patriotic self-expression. Only, in Athens it resulted in manifestations of art, literature, etc., while in Judaea, due to its religious form of life, it moved towards a reaffirmation of the religious spirit, and a developing pride in the history of the people. The first rost-Biblical historical works were therefore Palestinian.

1. The most important historical work of that period, a work which still exists, and which Josephus beyond a doubt used, (120) was haccabees 1. The work embraced the complete forty year period (175-135 B. C. L.) of the Jewish struggle until independence was obteined. It was on the historical-narrative order of the Bible, but told in a much more straightforward manner. Though its attitude was that of Pharisaic Judaism yet it is remarkable that there was in it "no expectation of miraculous intervention as distinguished fran providential support, and no hint of anything resembling miracles. Nor is there any trace of the religious pragmatism that (120) Schurer, History of Jewish People, $1 I^{3}$, note of p. 3 . 
is so strongly impressed in Kings and chronicles.

The work was written in Hebrew, and Josephus used it eithor in its original or translated form, Greek. Another work of the same order was The History of John Hyrcanus; as the work, however, is now lost, the use of it by Josephus remains doubtful.

These two historical works marked the PalestinianJewish interest in the new history. However, the confusion of the coming civil wars, together with a natural bent of Pharisaic Judaism to concentrate on more strictly religious themes, shifted the center of historical writing to the Diaspora--Alexandria, cyrene, Rome.

2. In the Hellenistic world, Jewish historical writings assumed a practical form. They were made to repel mainly Greek charges hurled against the Jewish people that they had no great past, and no records of their culture. It was partly in that motive that the famous septuagint version of the Bible was produced. For "no people could lay claim to be reckoned among the civilized nations, unless they could point to an old and imposing history." ${ }^{(122)}$ Cortain Biblical themes were also reworked

$$
\begin{aligned}
& \text { Moore, Judaism, i, p. } 206 . \\
& \text { schurer, History of Jewish reople, Div, } 1 I^{3}, \text { p. } 196 .
\end{aligned}
$$


by certain writers according to Groek taste; others tended towards the revision and completion of scripture literature. Thus the book known as the Greek Ezra treated the restoration period of Ezra more fully than the Bible. Josephus in his Antiquities conforms to its version. iistory was hence written both for instruction of one's own people and for making it accessible to the entire cultured world. The form historical works therefore assumed in the Diaspora was of non-soriptural Greek models. The first Jewish-Hellenistic historian, fragments of whose work we still possess, was Demetrius, who composed a work on the chronology of kings in Judaea, with special attention to dates, continued up to the time of rtolemy IV. The work reflected the interest in chronology that was beginning to appear, and which culminated later on in the universal conception of history. His suocessor, Eupolemus, also busied himself with chronology, and carried his computations down to about the year $160 \mathrm{~B} . \mathrm{C}$ (125) Fragments $^{\text {(125) }}$ of these works, as also of other Hellenistic historians, still exist in tusebius' rraeparatio Evangelica, which he took over from a certain Alexander rolynistor, who in one

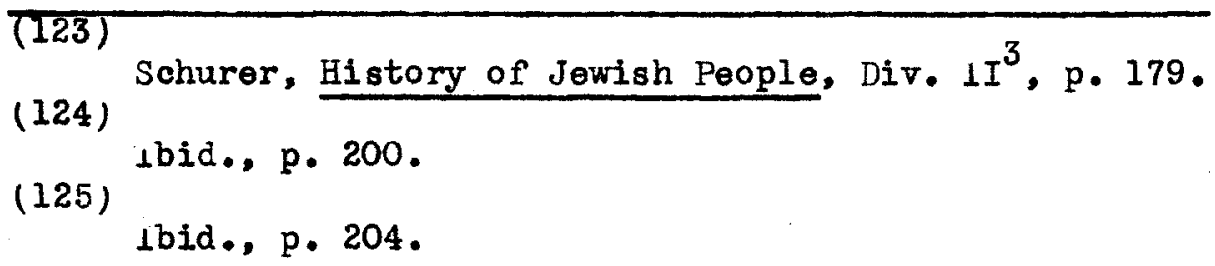


of his works rer1 Joudaium strung together extracts of authors concerning the Jews. Josephus betrays his acquaintance with Alexander's work in quite a number of (126)

places.

Strictly contemporary history appeared also in the works of a certain Jason of Cyrene who composed five volumes on the Maccabean struggle, which now exist in the condensed form, Haccabees $1 \mathrm{I}$. Josephus has a few points in common with that condensed form of the book. (127) The theme of Maccabees III, a Ptolemaean attempt of persecution of Alexandrian Jews, is mentioned by Hosephus in the older (128)

form of the narrative. Fhilo's account of contemporary

ovents remains in his two books we still possess:

The umbassy to Caius, and Against Flaccus. "The works are first class authorities for the history of this period. In addition Philo wrote on the kissenes, which Josephus copied in his description of the sects." (129)

A third category of Jewish-Hellenistic writings, of which Josephus made great use, was a group designated as "Jewish works under a Heathen mask." They had religious

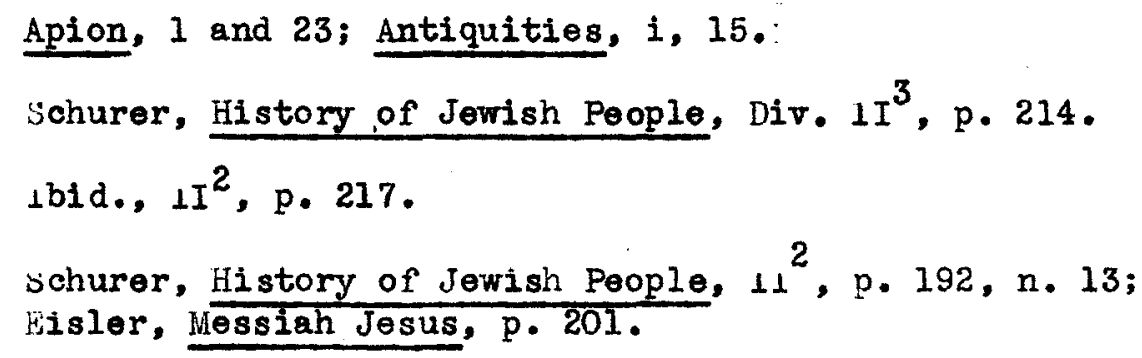


and national motives: "To set forth before the heathen world the folly of idolatry..... and the creating of a favoritable disposition towards Judaism and the Jewish law." (130) Portions of the famous sybelline oracles are (131)

very definitely Jewish. A passage of it, quoted in Eusebius' Chronology and taken from Alexander Polyhistor, (132)

is identically found in Josephus. Josephus' copying

from Alexander Polyhistor without mentioning his nome becomes clear.

Under the name of Hecataeus of Abders, a contemporary of Alexander the Great and Ptolemy Lagos, there existed a work on the Jews, treating of their relations with the first Greek monarchs. It is possible that there were some genuine portions of a work by Hecatreus to which later editions were made under the author's name. At any rate, (133)

Josephus admits his use of it.

The famous Letter of Aristeas on the origin of the Septuagint, being as it was a Greok admission of the excellency of the Jewish law, belongs also to that class.

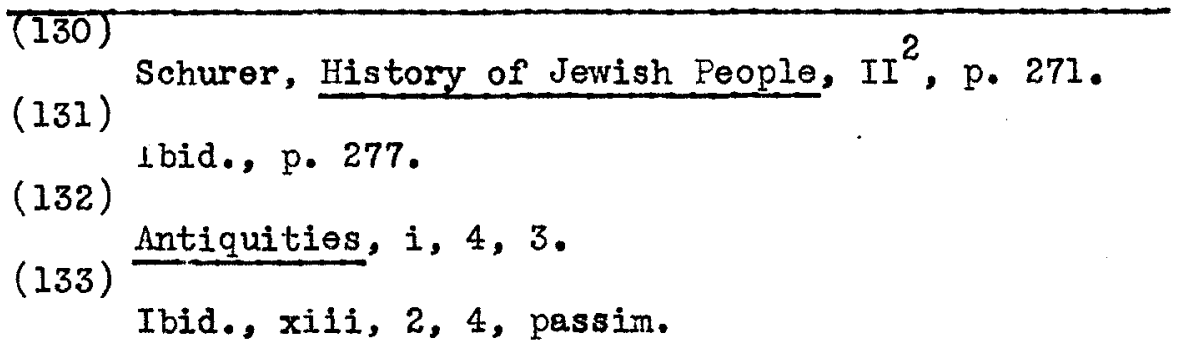


The Letter still exists, and from it we see that Josephus copied a great portion from it almost verbatim. 3. The final class of the general pre-Josephean sources is the group of classical authors dealing either directly or indirectly with matters of Jewish history. Thus it is known that Polybius in the sixteenth book of his history, now lost, dealt with the early relations of the Jewish people with Rome; Josephus quotes him twice. Strabo who, besides his geography, wrote an historical work continuing Roman history from the period where Polybius left off and ended at $30 \mathrm{~B}$. C. also dealt with the political history of Judaea and its religion. Josephus drew upon him to quite a good extent. (135) Livy too is mentioned once, and a host of other minor historians-as Asinion Pollio, Agatharchides of Cnidus, and others.

The most important classical work on Jewish history, however, was that of Nicolas of Damascus, a Greek savant who played many parts at Herod's court--secretary, minister, and diplomatist. He wrote a general history in 44 books in which he dealt with the history of the time of Herod and of Herod in particular. It is accepted by all critics

$$
\begin{aligned}
& \text { Antiquities, xii, } 3,3 \text {, } \\
& \text { Ibid., xiii, } 10,4 \text {, and passim. } \\
& \text { See Shotwell, History of History, p. } 120 \text {, note } 3 \text {. }
\end{aligned}
$$


that Josephus practically copies from him. "The disproportionate fullness, the vivacity, and the dramatic power of the narrative in books $x i v-x v i$ of the Antiquities are due in a large measure to the historical virtues of the court chronicler. (137) Josephus openly admits his thorough acquaintance with the history of Nicoles. (138)

(b) Particular Sources for the Wars and Antiquities

The general pre-Josephean works on themes of Jewish history, abundant as they are, do not exhause the list of ready material which Josephus used. There was still a very important group of sources relating to contemporary events which Josephus used in the composition of his history. His own admission of the use of them were drawn out of him perforce in the latter period of his life, when the veracity of his account was attacked by his enemies. Josephus, in order to substantiate the truth of his history, was even ready to admit the secret of his suocess. Thus, replying to the attacks of his rival historian, Justus of Tiberius, Josephus wrote: "Perhaps you will say that you have accurately narrated the events which took place at

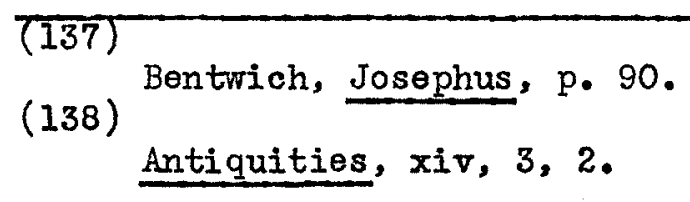


Jerusalem. How, pray, can that be, seeing that neither were you a combatant nor had you perused the Commentaries of Caesar, as is abundantly proved by your contradictory account?" (139)

The types of Commentaries then current were generally rough notes taken daily by the commander and afterwards reworked by professional hands. Certain accounts in the Wars remind one of field-notes taken from a military report. The peculiar geographical accounts of the districts of Palestine also bear a distinct Roman coloring. The description of the Dead Sea, also found with some striking (14I) parallels in Tacitus, bears out further the point that both Josephus and Tacitus must have drawn upon the same source, namely, Vespasian's Commentaries.

The second group of contemporary material that Josephus direotly used in the composition of his history comprised the important body of official documents written by Roman governors. Josephus' incorporation of thirty-four official documents in his Antiquitios, covering various items of importance throughout the entire Hellenistic and Roman periods, shows his access and general readiness of




using official, and perhaps originally archive, material. He used the reports of the governors for the period beginning with the accession of Archelaus and concluding with the outbreak of the last war. Hitherto, it had been customary to consider Josephus as having drawn his knowlodge of this period from oral traditions and memory. Eisler conclusively shows "that he did not compose his history of the Roman governors of Judaea from memory or after oral tradition but that on the contrary he used extracts from documents and followed them mechanically and closely."

Finally, there was a group of Greek and Roman versions of the war which Josephus had before him. He tells us of quite a number of popular accounts that appeared in Rome shortly after the Destruction. "The war of the Jews against the Romans.....has not lacked its historians. Of these, however, some, having taken no part in the action, have collected from hearsay casual and contradictory stories which they have then edited in a rhetorical style; while others, who witnessed the events, have, either from flattery of the Romans or from hatred of the Jews, misrepresented the facts." ${ }^{(143)}$ of the latter group, there (142) (143)

Iisler, Wessiah Jesus, p. 207; see there entire discussion pp. 201-218. Introduction to Wars, p. 1 . 
was a certain Antonius Julianus, a general on the staff of Titus, who participated in the siege and whose account on the destruction of Jerusalem was for a long time considered a standard authority. It is by far not improbable that Josephus' lack of sympathy with the Jowish cause in his own history went back to these popular versions current in Rome.

So to summarize the perticular sources of the Wars, we might say that beginning with his history up until the accession of Archelaus (Book II, Chapter 5) Josephus followed Nicolas. This portion of the work is characterized by its meagerness of knowledge of the Jewish background, and elaboration of the Herodian rise to power. From Archelaus to Agrippa I, Josephus was dependent upon official report documents of the governors. As these naturally did not treat his subject fully, he was bound to cover a period of sixty years in about seven chapters. (Book II, Chapter 5 - Chapter 12) He filled part of the gap by an account of the three sects, confining himself chiefly to the least important one, the Essenes, because he found ready material of Philo on it. From Agrippa I to the end, Josephus was already in his own time. For (144)

Bentwich, Josephus, p. 91. 
that period he had abundant sources--reports of the last governors, the commentaries of Vespasian and Titus, personal notes he had taken while witnessing the siege (145)

of Jerusalem, and oral conversations with Agrippa $1 I$.

Toward the end of the Nars, there are a few chapters

that show very evident marks of coming from a history whose

theme was the life of Vespasian.

As for the Antiquities, the first eleven books, dealing as they do with the Biblical period, Josephus was not strictly an historian but merely a transmitter; the account nevertheless is of great interest from other angles, namely, Biblical textual criticism, the development of Jewish Hagaddah, Jewish-Hellenistic apologetic trends, etc. From Book $X_{\perp} I$ on, the narrative is proportionate according to the nature of the sources. It is short on the period of Alexander the Great, as Josephus used the account of Agatharchides of unidus' Aots of Alexander's Successors, which naturally would not supply him with much matorial. The Letter of Aristeas, and other documentary material showing the status, rights, and honors that were given to Jews by rulers and cities of the Near East, brought his history up to the period of Antiochus the Great. (145)

Apion, p. 49 .

e.8. Book V1I, Chapter 7. 
Maccabees 1, Nicolas' work of the seleucid smpire, the chronical of John Hyrcanus, and Strabo's work supplied Josephus with material up to the civil wars of the Hasroneans and the coming of the komans (Book XIV).

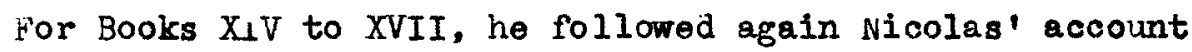
of the life of Herod, but now with a certain sense of discrimination. The cause of this new tone was due to his coming into possession of a now source on that period, namely, Herod's Commentaries, which he could compare with the version of Nicolas. For the last three books, Josephus used again official records of the governors, digressed on the reign of the Emperor Tiberius, and the assassination of valigula. For these latter chapters, he used a Latin source, probably by harcus $C$. kufus. (148) The Antiquities were finally brought up to the outbreak of the last struggle against Rome. (c) Extent and Method of Josephus' Way of using Sources The preceding analysis of the sources of Josephus' history would have been of no great importance were it not for the fact that an investigation of the sources there still exist points to the conclusion that he did not at all arise above them. The utmost originality he (147)

Antiquities, $x v, 3,8$. Thackeray, Josephus the Historian, p. 69. 
knew was that of taking the substance of a story and telling it in his own way. He would then be paraphrasing his sources. To be exact, absolute originality is hardly expected of an historian; without sources to build upon, one's effort must remain in the dark. But it is one thing to utilize certain selective facts of sources for the purpose of relating them to some general problem of history, and another, merely to use them with no discrimination. The former method results in a unified account; the latter, in a history which is incongruous and confusing. Also, in the former kind, once the author's point of view is grasped, it is possible to anticipate his general conclusions; in the latter, it is only by a study of all the separate sources that one is enabled to understand the work at all. As Josephus: history is of the second type, it is clear why the sources he used must be established. For, in a word, they alone can clarify and account for the motley of discordant motives we will find in his history

But first we need definitely to demonstrate the nature of his way of using sources. We will take three examples, though the number could be multiplied wherever the sources are avallable. 
1. A comparison of Josephus' version of the Maccabean struggle with the book of fraccabees I reveals on part of the former a close adherence to his source, with an oocasional paraphrasing of speeches and other minor matter. Examples are too comprehensive to permit quoting on too large a scalo, but it is a fact that wherever one turns to parallel incidents of the two books, one is immediately impressed with their striking similarity. Thus to choose one at random: The incident is of the rising of Judas Haccaber. Josephus tells it in the following words: (149)

"Mnen Apollonius, the general of the Samaritan forces, heard this, he took his army, and made haste to go against Judas, who met him, and joined battlo with him, and beat him, and slew many of his men, and among them Apollonius himself, their general, whose sword being that which he happened then to wear, he seized upon, and kept for himself; but he wanded more than he slew, and took a great deal of prey from the enemy's camp, and went his way. But when seron, who was general of the army of celesyria, heard that many had joined themselves to Judas, and that he had about him an army sufficient (149) Antiquities, xii, 7,1 . 
for fighting, and for making war, he determined to make an expedition against him, as thinking it became him to endeavour to punish those that transgressed the king's injunctions. He then got together an army, as large as he was able, and joined to it the munate and - wi cked Jews, and came against Judas."

The original account in Maccabees reads as follows :

"And Apollonius gathered a great army of foreign mercenaries and samaritans to war against 18 rael. Whon Judas heard it, he met him, and smote him and slew many of his men. He took their prey and girded on the sword of Apollonius and kept it as his sword of vengence all his life. When Seron, general of Syria, heard that Judas had gathered a great body of people for war, he took his chariots and army to go to punish 1 srael and came as far as Bethhoron."

The last few chapters of Maccabees Josephus did not reproduce; but the cause of it was not that he repudiated their trustrorthiness, but that his copy of the book simply did not contain them. (15I) His general method was thus clearly of following closely his sources,

(150)

Maccabees 1,3 , vs. 10-15.

Thackeray, Josephus the Historian, p. 62 . 
with an oocasional Hellenization of its form.

2. In his use of the Letter of Aristeas,

Josephus reveals a still further. slavish adherence

to the source he had before him. He simply followed

it step by step and inserted small changes to edify

further the esteem and honor of his people held by the

Htolemaean ruler. Detailed comparisons of parallel

accounts illustrate the same method as he used in

Haccabees.

3. A final example, the breach of John Hyrcanus, is of a more interesting though complicated nature.

The external evidence there exists to check up on Josephus' version of that incident speaks quite clearly with a different tone, and as such could not have been the one used by Josephus; yet it permits to see the nature of the source Josephus used, and how closely he followed it. The incident goes back to the sudden break of John Eyrcanus with the tharisees in the middle of his reign, and his consequent alliance with the aggressive policies of the Sadducees. The cause of that breach has been a subject of interest already to the ancients. Josephus and the Talmud tell a story, which though legendary in parts is yet regarded to be authentic (152)

in its general outlines. The essential agreement of (152) Schurer, History of Jewish reople, $11^{2}$, p. 27 . 
the content of the two stories, with only a difference of coloring, presents an interesting comparison. Josephus tells the incident in the following words:

"The prosperous state of affairs moved the Jews to envy Hyrcanus; but they that were the worst disposed to him were the tharisees.... ilyrcanus was a disciple of theirs, and greatly beloved by them. And when he once invited them to a feast..... when he saw them in a good humour, he began to say to them, that they know he was desirous to be a righteous man..... However, he desired, that if they observed him offending in any point.... they would call him back and correct him. Un which occesion they attested to his being entirely virtuous.... But still there was one of his guests there, whose name was bileazar, a man of an ill temper.... This man said, 'since thou desirest to know the truth...lay down the high priesthood, and content thyself with the civil govermment of the people.' And when he desired to know for what cause he ought to lay down the high priesthood, the other replied, We have heard it from old men, that thy mother had been a captive under the reign of Antiochus Epiphanes.' This story was false, and Hyrcanus was provoked against him; and all the (153) Antiquities, xiii, 10, 5-6. 
tharisees had a very great indignation against him.... Now there was one Jonathan... of the sect of the jadducess.... who told Hyrcanus that wleazar had cast such a reproach upon him, according to the comnon sentiments of all the Pharisees, and that this would be made manifest if he would but ask them the question, What punishment they thought this man deserved?.....the Pharisees made answer, that he deserved stripes and bonds, but that it did not seem right to punish reproaches with death.....At this gentle sentence, Hyrcanus was very angry..... It was this Jonathan who chiefly irritated him, and influenced him so far, that he made him leave the party of the Pharisees, and abolish the decrees they had imposed on the people, and to punish those that observed them."

The Talmud refers to the same event in the following manner:

"An incident relating to King Jannai (Hyrcanus) who.... captured sixty fortresses. Un his return he made great rejoicing, and he called to all the wise of 1 srael and said to them 'our fathers used to eat salted herbs while they were engaged in building the Temple. Let us also eat salted herbs in memory of our fathers.' And they served salted herbs upon golden tables, and they did eat. Ihere was one there, a man of mockery, of a 
bad heart, a vile fellow, by the name Eleazar ben Poirah.... He said to King Jannai 'King Jannai, the heart of the Pharisees is against thee.' 'And what shall 1 do?' 'Prove them by means of the gold plate which is between thine eyes.: And he proved them by means of the gold plate (154)

which was between his eyes. There was there an old man, by name Jehudah ben Gedidiah. And Jehudah ben Godidiah said to King Jannai, 'King Jannai, enough for thee the crown of royalty; leave the crown of priesthood to the seed or Aaron.' For people said that his mother had been a captive in liodiim. And inquiry was made but no truth was found in the report. And the is of Israel withdrew in anger. And Eleazar ben Poirah said to King Jannal, 'King Jannal, such is the treatment of a private man of 1srael, and such is the treatment of thee though thou art King and High Priest.' 'And what shall $\perp$ do?' 'If thou wilt hearken to my counsel, crush them.' 'And the Torah, what will become of that?' 'Lo, it is rolled up and left in a corner. who so wishes to learn let him come and learn.' And straightway the evil sprouted through the act of Eleazar ben Poirah, and they slew all the Wise of Israel, and the world was desolate until Simeon ben shetah came and restored the Torah to its (154)

Symbol of the dignity of the high priesthood. The native city of the Haccabees. 
former state."

A close comparison of the two versions of the same incident reveals, first, that the document Josephus used was that of an author who was not favorably dis(157)

posed to the Pharisees; secondly, that he copied the incident as he found it, for otherwise, the two accounts would not have been so strikingly similar. The extent and method of Josephus' use of sources are thus clear. He used anything that presented itself to him as material for his connective story of two thousand years of history. He compiled his story-used sources with no particular regard for their veracity or points of view they attempted to present. To stamp his work with the mark of originality, he would often paraphrase his sources and insert minor changes in them. It is true that this method was part of the ethics of the historians of Josephus' time; the significance of it, for our purpose, is, however, not minimized, namely, that due to his compilation of sources we are to anticipate a number of conflicting points of view in Josephus' works. The singling out of these various motives and personal prejudices will hence be our next concern.

Tractate Kiddushin 66a

Probably Nicolas. 
B. Point of View: Motives and Prejudices

In his happy-go-lucky way of using sources,

Josephus might have produced an encyclopedic history

of raw and original sources which would have been of

great use to future students of history. His serving,

however, of too many masters at a time impeded even that

possible merit of his writings. The little changes that

he would make here and there produced curious distortions

that seem hardly believable to have come from a man who

was conscious of the meaning of things ho was writing or copying.

Generally these causes or motives may be divided into two groups: Those of an immediate nature and those of remote effect.

(a) Immediate hotives

1. Flavian

The most immediate object of Josephus' writing was that of serving his masters, the Flavians, to whom he owed his life and liberty, and from whom he had received the commission to write. This aim appears quite frankly in Josephus' first few words. "The prestige of the generals will be deemed inglorious if what they achieved will be reckoned but a small matter." (158) Josephus, or really the Emperor, was afraid that the military accomplishments of the new imperial family will be underestimated and that (158) Introduction to Wars, 3 . 
their prestige would suffer. It was therefore necessary to play up before the Roman world the herculean labors that the Hlavians had to undergo in the Judaean war. The full significance of this motive can be seen more clearly through a larger historical perspective of the Flavian house. The year of the four emperors, 69-70, had found Vespasian far away from Rome. He was in Judara, there occupied with the military task he had received from Nero. When his legions proclaimed him emperor, and he was bound to leave his son Titus in Judaea to conclude the war, while he journeyed off to Alexandria and then to Rome, it was a simple matter for the father and son to see that their claim to prestige and honor would greatly be advanced if the uprising in palestine were quelled completely and quickly. The triumph against Judaea was therefore the first triumph of the Flavians by which they demonstrated their service to the koman state. The greater a historian would paint the wars, the better would then the cause of that family be served.

It is for this reason that we find Titus very anxious to bring the war to a hasty and succossful ending. "He (Titus) feared, moreover, that the glory of success would be diminished by the delay; for though time could 
accomplish everything, yet rapidity was essential to (159)

renown." This account may well be considered one of

the many "slips" of Josephus, for the ground meaning

behind it is cloar. Titus was aware of the need of a

good reputation that the newly-proclaimed imperial family

must establish, and that an undue length of time spent

in its struggle against the Jews would reduce the

glory of the success in the eyes of people at Kome.

This Flavian motive also accounts as to why Titus

was so ready to put the imperial seal of consent to the

Wars, why he ordered a copy of it to be placed in the imperial library, and lastly as to why he was so anxious that Josephus" volumes "should be the sole authority from which the world should learn the facts." (160) For Josephus cortainly did succeod in pleasing Titus by raising the revolt of the Jews to nigh a world theme.

That was one aspect of the service Josephus was bound to render to his masters. In a more personal way, he was to show above all the magnanimity of the characters of this new family. This motive appeared, first of all, in Josephus' announcing time and again that the Emperorship

(159) Wars, v, 12, 1.
(160)
Life, p. 65.


was forcibly pushed upon Vespasian, contradictory to his will. "When he refused the empire the officers pressed him more insistently and the soldiers, flocking round with drawn swords, threatened him with death, if he refused to live with dignity. After forcibly representing to them his many reasons for rejecting imperial honours, finally, failing to convince them, he yielded to their cal1." ${ }^{(161)}$ It was in fact an act of Providence that directed Nero to appoint Vespasian to the Judaean task; it was the paving of the way for Vespasian being himself (162) emperor afterwards. Later on, during the eventful year of 69-70, "it is God himself who erects the general's expectations so as to think of obtaining the Empire." Josephus' flattery to Titus knew of no limitations. He never tired of pointing out the generosity of the man, the readiness with which soldiers followed him, his valiant character without which the war could not have come to a successful ending. Soldiers in leaping to death would have their gaze fixed upon his face to carry its impression with them as a sepulchral monument. Josephus was at times conscious of his flattering; but it is the truth, he (161)

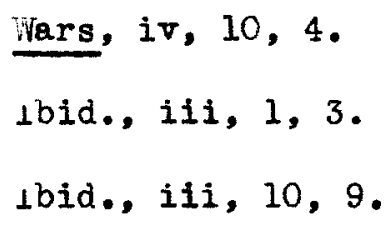


assures us, that was forcing him to do it.

furthermore, was the ideal general, merciful and

considerate even to the vanquished. He always believes

"that it was better to let a guilty person alone in

his fears than to destroy with him any one that did not deserve it; for that probably such a one might be taught prudence by the fear of the punishment he had deserved, and have a shame upon him for his former offences when he had been forgiven; but that the punishment of such as have been once put to death could never be retrieved." Titus was a born prince. Providence itself diverted stones (166)

and darts from touching his body. Josephus' praise extended even to Domitian, the second and youngest son of Vespasian. When news of the revolt of the Germans reached Rome, "and laesar lomitian was made acquainted with it, he made no delay even at that age, when he was excerding young, but undertook this weighty affair. He had a courageous mind from his father, and had made greater improvements that belonged to such an age...ile retarned to kome with honour and glory as having performed such exploits as were above his own age, but worthy of so great a father."

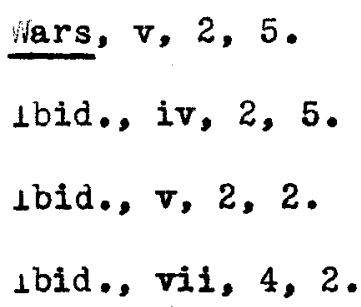


Josephus certainly knew whom and how to flatter. He may woll be called the first press-agent of the Flavians. The many perversions of facts that resulted from this motive of Josephus may generally be observed throughout the entire history of the Nars; some specifically are almost incredible to have come from his pen. We will mention two examples.

Josephus alleges to have been an eye witness of all the important scenes that transpired in the Roman camp before the walls of Jerusalem. Yet when describing the council of the Romen staff as to whether the Temple should be burned or left intact, he makes Titus declare that the Temple should not be touched. (168) It took an historian of the second century, sulpicius severus, to let the truth out, namely, that the responsibility of (169)

the act rested solely upon litus. In the contradiction of these two sources, modern historians have conclusively shown that the account of severus to be reliable. Josephus the eye witness of the scene must have simply had either a distorted eye-sight or a pen that would pervert the veracity of facts to suit the wishes of his patrons. The second example goes back to a transaction of (168)

$$
\begin{aligned}
& \text { Wars, vi, } 4,3 . \\
& \text { Sohurer, History of Jewish reople, } 1^{2}, \mathrm{p} .244, \mathrm{n}, 115 \text {. }
\end{aligned}
$$


Vespasian in Galilee. After having conquered some cities, he had given his hand to peaceful citizens of certain communities to assure them of the safety of their lives. However, as Vespasian's counselors were too hard for him "and pretended that nothing against the Jews could be any impiety...so he gave them (the Jews) an ambiguous liberty to do as they advised, and permitted the prisoners to go along no other road than that which led to Tiberias only. They readily believed him and went along securely the way which was allowed them, and he shut them up in the city. Then came Vespesian, and ordered them all to stand in the stadium, and commanded them to kill the old men together with the others that were useless, which were in numbers a thousand and two hundred. Uut of the young men he chose six thousand of the strongest and sent them to Nero, to dig through the 2sthmus.... for the rest of the multitude.... the greatest part of them were seditious persons and fugitives, who were of such shameful characters that they preferred war before peace." The account, outrageous and almost unbelievable, is softened by our Jewish historian that it was Vespasian's friends that urged him to commit the act, and that some (170) wars, iii, 10, 10. 
of the Jewish men in the group were of such "shameful" character that they preferred war before peace. Indeed, what a sin!

\section{Herodian}

The second, next important in rank of Josephus' patrons was his friend Agrippa II, King of chalcis, an Herodian by birth. Being pro-koman throughout the war, and fighting his people together with Vespasian in Galilee, and with Titus in Judzea, he was the star of second magnitude in Josephus' history. His degenerate character one may know from certain rumors that circulated in Rome (171) about him and his sister Berenice, but more definitely from the incident of Vespasian just cited. There we learn that the-Roman general had given him some of the prisoners as a gift. "But the king sold them also for slaves."

That was quite a considerate act for a king to do to his people.

Agrippa received his share of importance in Josephus' history when the author credited him with the delivery of an oration on the Roman Empire to deter the people from revolt against Rome. The speech, perfectly organized as it is, and concentrated with a vast knowledge of conditions in the Roman umpire, is indeed a flattery to Agrippa. TII) (172)

schurer, History of Jewish reople, $1^{2}$, p. 195. Wars, iii, 10, 10 . 
A Roman could not have presented his case better than did this Jewish king. It was worth while to have such an oration written to one's credit when one still entertained the possibility of becoming a brother-1n-law to Titus. (173)

The distortions of facts that this Herodian motive led to on part of Josephus are also numerous. Two examples will suffice. In the causes of the war, the tyranny of the Herodian family was quite a determining factor as that of the Roman governors. In fact, Josephus lets his pen slip in one place by admitting that the Jews "did not so much object to the Romans as to the tyrants of the Herodian dynasty: Generally, however, that aspect of the causes of the war Josephus quite well concealed. He clearly ascribed the war to the rapacity of the governors alone. It is possible that this part of Josephus' task, namely, the blackening of the reign of Nero and his system of government--was but a means of directing ioman attention to the orderly management of affairs by the Flavians. But at any rate, it is noteworthy that Josephus managed to eliminate completely the Herodian responsibility of the war.

(173) schurer, History of Jewi sh People, ${ }^{2}$, p. 203.
(174) Wars, ii, 6, 2.


A second example appears in Josephus' account of Agrippa LI's father, Herod Agrippa 1. That king, it will be remembered, had proven hinself to be the exception of his family. He was one king of that period who was heartily devoted to the welfare of his people. In Jewish sources, he appears in remarkably beautiful light. Now it is of Agrippa I that Josephus in the early portions of his Wars tells of his "beginning to encompass Jerusalem with such a wall which, had it been brought tho perfection, had made it impracticable for the komans to take it by siege; but his death, which happened at lesarea, before he had raised the walls to their due height, prevented him." Further on in the narrative, the language is more clearly (176) to the point. It is there indirectly suggested that the king was not free from a suspicion of wanting to break loose from the Romans. But to state that openly, Josephus obviously could not afford, bocause of his friend Agrippa II; it cortainly would have been against the interests of the latter to let Romans read that his father contemplated such an act. In the Nars therefore Josephus had to pass over the facts in silence; in the Antiquities when Agrippa was already dead, he expatiated on it more fully.

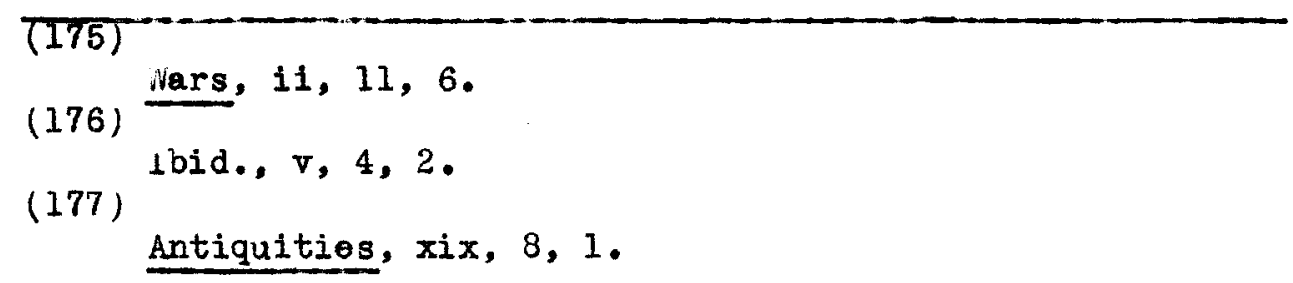


3. rersonal

Not least of the interests Josephus was to

serve in his history was that of his own self. He was to show his own ability as a Jewish general and tactition, and yet prove at the same time the odium he entertained for his former life. He was to demonstrate before all his deep-seated sympathies with Roman life, and how perfectly he had adjusted himself to its standards. Accordingly, we read in his history that as soon as he took over the commission in Galilee, he drilled his (178)

soldiers on koman Lines. His picture of himself throughout the wars was that of a pure, faultless person aiming solely for the welfare of the people. "As to Josephus when he came into Galilee, his first care was to gain the good will of the poople of that country, as sensible that he should thereby have in general good success, (179)

although he should fail in other points." He preached to them laws of conduct and behavior in war. His opponents were of course downright villians. His picture of his enemy, John of Gischala, was as black as that of catiline by sallust. (181)

With such simple, pure, and precise motives, Josephus' (I78) Nars, ii, 20,5 . Ibid., ii, 20,5 . Ibid., ii, 20, 7 . Josephus, Vol. 1I, (Loeb Classical Library) p. xix. 
activity in Galilee ought to have been clear in meaning and free of suspicion. Yet he has produced there an account of his activities that is so doubtful that it has aroused the distrust of all students; in fact, it might generally be said that wherever Josephus had a personal interest in an event, he so perverted the account of it that it is almost beyond redemption. In addition to his personal interests which the historian had to serve, Josephus was not void of the art of flattering himself. Thus, when news of Josephus' retiring to the fortress of Jotapata reached Vespasian, our historian in all his modesty made the Roman general to have believed it "to have been brought about by the providence of God that he (i.e., Josephus) who appeared to be the most prudent man of all their (the Jew's) enemies, of his ow accord shut himself up in a place of sure custody."

His acoount of his tactics on the walls of Jotapata, as the pouring of seething oil upon the enemies below, in itself a trite stratagem of all ancient siege warfare, he claimed as his own invention. Generally all these tricks could have easily boen copied from any standard book on war. But Josephus, of course, was to show what wars, iii, 7,3 . Eisler, Messiah Jesus, p. 198. 
a difficult opponent Vespasian had before him in his siege of that fortress.

4. Roman

A fourth immediate cause Josephus was to serve in his writings was that of the Roman state. He wrote for the "upper barbarians" of the Euphrates, Jews and Parthians, to produce upon them calming effects not to stir up a fresh revolt. In itself, this notive of turning history to practical ends was quite legitimate. But Josephus overdid it to such a degree that his history has the eppearance of a paean on Roman arms. His thesis was nothing less than that God is behind Roman arms, and that the nation that revolted against the Romans challenged thereby the will of Providenoe. (184)

This conception produced some astounding results. Thus, in the account of the defeat of lestius Gallus by the Jews, Josephus justifies the Roman foilure on the basis of the following thought:

"It was, I suppose, owing to the aversion God had already at the city, and the sanctuary, that he was hindered from putting an end to the war that very day."

In other words, would Gellus have been successful in his queling the revolt of the Jews at its beginning,

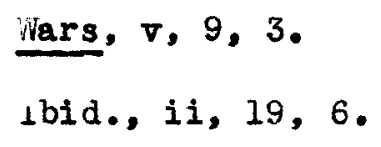


Jerusalem and the Temple would have remained. But as there was already an aversion of God to the city and sanctuary, it was therefore necessary to drive the Jews further on to their destruction by giving them one victory to stir their hopes for a final success. What an apologetic sham to have come from Jewish authorl One of his flatteries to the Roman army is worth mentioning. Having given a description of the koman armies and camps, their manner of warfare, etc., he expressed surprise as to why the Romans have not conquered the entire world. "One might well say that the Roman

possessions are inferior to the Romans themselves."

The concluding remarks of that chapter openly avow the political motive of Josephus' history. "If 1 have dwelt at some length on this topic, my intention was not so much to extol the Romans as to console those whom they have vanquished and to deter others who may be (187)

tempted to revolt."

$$
\text { 5. Jewish }
$$

Last of the irmediate causes Josephus was to advance was that of his own people--of demonstrating to the Roman world that the final revolt was not a voluntary act of the masses of the Jewish people, but was forced (186)

Wars, iii, 5, 7 .

Lbid., iii, 5,8 . 
upon them by a few hot-heads, the zealots. It was an attempt of removing the war-guilt placed upon them by the Romans. As such, the aim of Josephus in this respect reveals the author in quite a charitable light. But his value as an historian is again thereby marred. For laboring to do his utmost in olearning away the people's guilt in the war, he drew entirely a false picture of the nature of their part in that struggle.

He pictured the leaders of the war as arch-devils. "The city, wrapped in profound silence and night laden with death, was in the grip of a yet fiercer foo-the brigands. For breaking into habitations that were now mere charnel-houses, they rifled the dead and stripping the coverings from the bodies departed with shouts of laughter; they tried the points of their swords on the corpses and ran them through some of the prostrates but still living wretches, to test the temper of the blade, but any who implored them to lend them their hand and sword they disdainfully left to the mercy of the famine."

There was no stinging description strong enough for Josephus to describe sufficiently the barbarity of the war leaders. "They were the slaves, the scum, and the spurious (188) Wars, $\nabla, 12,3$ and passim. 
and abortive offspring of our people..... Indeed when they saw the Temple burning from the upper city, they were neither troubled at it, nor did they shed any tears on that account, while yet these passions were discovered among the Romans themselves." (189)

It is with such fabricated desoriptions that Josephus wanted to create the impression that the leaders were alone responsible for the war. But this version of the attitude of the people is challenged by a whole array of evidence. Tacitus speaks of the extent of the war in the following words :

"All who were able bore arms, and a number, more than proportionate to the population, had the courage to do so. Men and women showed equal resolution, and lifo seemed more terrible than death, if they were to be forced to leave their country." (190) secondzy, it is a fact that the people remained with their leaders to the end. There may have been inner party jealousies; but as to the itself against Rome, there is no doubt that its kindling was a spontaneous outburst of the poople against outrages from which they had suffered for almost a century. It was a war joined by all classes, excepting the Herodians. Even the proselyte Adiabeness fought with the people to the (191)

end. To make therefore the final revolt appear solely (189) Wars, $\nabla, 10,5$ (190) History, $v, 13$. (191) Mars, ii, 19, 2 and passim. 
as an act of a few irresponsible leaders, who be a reign of terror forced it upon the entire people, may be good apologetics but simply not the truth.

The fact of the matter is that Josephus deliberately omitted a potent factor in the causes of the war, namely, the Messeanic hope. Nowhere in the wars is there any direct mention of this tremendous religious -political phenomenon which was part of the background of the hopes and expectations of the people. 1 found only two remote references to the Messeanio conception. The clearer one reads as follows:

"But what more than all else incited them to the war was an ambiguous oracle, likewise found in their sacred scriptures, to the effect that at that time one from their country would become ruler of the world. This they understood to mean someone of their own race, and many of their wise men went astray in their interpretation of it." (192)

It will be noticed that even here Josephus did not openly refer to the liessianic belief. The reason why Josephus passed it over in silence can easily be gathered from other literature of that time where it appears that (192) itars, vi, 5, 4; the second reference is found Ibid., vi, 5, 2 . 
the word Messiah was taboo to the Romans. To give even the slightest consideration to this hope of the people would have therefore meant a betrayal of his thesis, that the people were not guilty at all in the war against Rome. Josephus was hence bound to work out an artificial condition, where the responsibility of the revolt would fall upon a few tyrants who drove on the people to do things against their will. It was in this manner that Josephus thought of serving his nation. He could have of course accomplished his purpose by showing that the people did not originally rise so much against the Romans as against the tyranny of a few officials, governors, and Herodians--an account which would have been indeed nearer to the truth than his fabricated story of the unwillingness of the people to be engaged in the war. But as this method would have affected his friend and patron, Agrippa, Josephus was forced to circumvent his way and demonstrate the same thesis from another angle. The result is an artificial account of the opposing forces involved in the war. The war appears as simply meaningless--a huge mistake.

It is remarkable that it took students, other than eye-witnesses, to behold the meaning of that struggle, and the glory of those heroes that fought the war out sterdfastly to the end. (193)

Goorge iliot, Impressions of Theophrastus Such., Chapter 18. Goodman, History of Jews, p. 38 . 


\section{(B) Remote Motives}

The final motives that played a prominent part in Josephus' writing of his history were those of a more distant effect. They may all be grouped under the one following problem.

1. Pure Historical Hotive of Antiquities

On reading the introduction to the Antiquities one is impressed with a certain genuine sincerity as to the author's intention of having undertaken his "magnum opus". It is a fact, he tells us, and he certainly knows it from his own experience, that histories are at times written "to gratify those that happen to be concerned in them, and on that account its writers have spared no pains, but rather gone beyond their own abilities in their performance." (194) But the incentive that induced him to write was purely of an inner personal nature. He felt the importance of his theme, and its beckoning to him of being "drawn out of darkness into light". It was a theme he thought worthy of study. And while he had his doubts as to the existence of an audience interested in such an endeavor, he had hope "to suppose there might even now be many lovers of learning." (195)

This being his original intention in the composition of his Antiquities, it speaks well for Josephus that at (194)

$$
\text { Introduction to Antiquities, } 1 .
$$

Lbid., 3 . 
least in thought he rose to a fine conception why he wrote his history. In its concrete realization, however, Josephus' conception of the intrinsic worth of his theme gave way to questionable results. It meant a deliberate intent on part of the author to impress his readers with the greatness of his people, and the meaning and value of their religion. Incidents which would throw an unfavorable reflection had therefore to be eliminated; laws which might of fend the tastes of his readers had to be omitted. In general, his history had to approach the accepted standards of his times in religious, moral, and philosophic conceptions. Josephus thus aimed to produce a history of his people which would make even their vilest enemies bow in recognition of their greatness. That was the practical bearing of Josephus' original pure motive in writing his Antiquities. There are virtually innumerable changes and twists that cover the pages of the work. For our purpose, two examples will suffice. He omitted the story of the worship of the Golden calf for the obvious reason that it woulc not refloot favorably on the character of his people. Again, he expatiated on Solomon's dedicational prayer of the Temple imploring God not for the Hebrews alone but for all nations. So far Josephus followed the Biblical text. But he added to the prayer the following words of solomon: 
"For here all shall learn that Thou wast pleased with the building of this House for Thee; and that we are not ourselves of an unsociable nature, nor behave ourselves like enemies to such as are not of our own people; but are willing that Thy assistance should be communicated by Thee to all men in common, and that they may have the enjoyment of Thy benefits bestowed upon them." (196) The desire to create an impression is right on the surface. Another practical result of Josephus' primary motive was his marked coolness to the Pharisees, and warm admiration for the Essenes. The Pharisees, with their intense religious consciousress and uncompromising loyalty to duties of faith, were subjects of contempt to the Groeks and Romans that came in contact with them. Their teachings, instructive and inspiring in themselves as they were, could only be appreciated by. those who shared their inner life. But outwardly the average Pharisee with his separatistic tendencies must have appeared as a fanatic. Josephus could not champion this type of a man in his history. No amount of glorification could accomplish that aim. Consequently, there is not a single trace of real Pharisaic Judaism in his history. (196)

$$
\text { Wars, i, 25, } 7 \text {. }
$$


Of the ethics of the kabbis, which would have really furthered his general theme, there is no mention. Even the prophets appear in a very superficial light. The few statements he has on the teachings of the Pharisees are bare of any insight, and always unsympathetic in tone. It is true, Josephus pointed with pride to the loyalty of his people to their religion, to their readiness of even becoming martyrs--a phenomenon which anyone acquainted with Jewish history will know to be a purely tharisaic development--but he dared not to present it in that light. The vital content of Pharisaic Judaism he therefore completely ignored. He was careful to inform us of the name of a certain concubine that Herod presented to his son, while the name of the great Hilell was found to be so unimportant as not to be mentioned even once.

It was different with issenism. The semi-ascetic tendency of its life, the mystery of customs with which the group was surrounded, its belief in augury and dreams-these were things already intelligible to the average Greek and Roman. Josephus did therefore his best to show from this angle the effinity between religious conceptions of his people and those of the Greco-Roman world. The field offered opportunities for every turn or fancy. 
"They (the kissenes) show fidelity to all men, and especially to those in authority; because no one obtains the government without God's assistance.... (197)

They esteem death better than living....there is never any clamor or disturbance to pollute their house, but they give everyone leave to speak in their turn; which silence thus kept in their house appears to foreigners like some tremendous mystery. (198)

In essence Josephus' method seemed to have worked on some line as follows. The greatness of the Jewish people will be demonstrated by showing their history and religion to possess elements akin to those of the Greeks and Romans. It was by concentrating on this formal relationship between Essenism and paganism that Josephus thought of serving best his people. We see thus what happened in the end to Josephus' original urge of writing the Antiquities. He had conmenced to write it with a desire to bring to life the history of a people that was "worthy of study to all the Greeks"; he ended with a history wich, like the author in his private life, made flatteries to Greek and Roman tastes. (197) (198) Wars, ii, 8, 7 . Lbid., 2, 8, 5 and passim. 
C. Uredibility

With the foregoing conclusions, as to sources and motives in mind, there is not much left to consider as to the question of the degree of credibility to be attached to the history of Josephus. It becomes clearly a composition where statement and proof bear remote relations to one another. It is of course possible to. extract from it in most cases a substratum of facts and reinterpret them on new lines. But as such, every episode must be judged separately as to veracity, significance, etc. "Beneath all his (Josephus') partisanship and his rhetorical language lies a goodly nucleus of important information." (199) To discover that "nucleus" is to find the only thing that is trustworthy in Josephus writings.

The degree of credibility of Josephus' history cannot thus be estimated in a constant term; it must differ with each separate episode.

$$
\text { D. Rationality }
$$

The problem of cause and effect in the general development of historiography is an important one. It reflects the mental life of historians, their manner of regarding the pessing events of life. The early attempts (199) Encyclopedia of Keligion and ththics, art. "Josephus", 
of historians to ascribe certain episodes to the miraculous intervention of a divinity are indications of the supernaturalism that characterized their minds. Un the other hand, retention of miracles together with an attempt to rationalize them presents the emergence of naturalism, though not completely freed from the older conception.

Josephus belonged to the latter class. He was a wavering rationalist. He recounted miracles, and then to convince himself of their plausibility he cited similar Greek and homan miraculous accounts as if to gather courage from them to present his stories with equanamity. Thus, if 1 srael's passing of the ked Sea appeared as unnatural, a similar providential act that happened to Alexander the Great, and told by Greek historians, gave him confidence to consider his story as equally sound.

This was Josephus' general method in presenting miracles. It clearly points to a mind that mentally has risen already above the crudeness of belief in supernaturalism, but nevertheless accepts miracles because better people than he still believe in them. A mental servility on part of our historian to his environment is thus marked even here. 
Where there were no direct miracles to account for, Josephus regarded epochs of history as guided by Providence along ethical lines. In essence, that was a pure Hebraic conception; however, in the hands of Josephus it eventuated in some Hellenized platitudes as the following:

"The reward of felicity is proposed by lod.... (200)

Virtue is its ow principal reward.... wicked actions do not escape the divine anger, nor is justice too weak to punish offenders, but in time orertakes those that transgress its laws, and inflicts its punishment upon the wicked in a manner so much more severe, as they expected to escape it on account of their not being punished immediately."i (201)

These thoughts are of course all Hebraic in content, but not in one instance is there to be found in them the Biblical loftiness of thought or vigor of expression.

In addition to these basically Hebraic conceptions, Josephus reveals surprising number of Greek religious ideas applied to history. Thus, the success of a king excited the jealousy of Providence. "Fortune was avenged

Introduction to Antiquities, 3. wars, vii, 2,1 
on Herod in his eternal great success." (202) Herod murdered his sons, "the ghosts of Alexander and Aristobolus go around the palace and become the inquisitors and discoverers of what could not otherwise be found out." (203) when the hour of fate strikes no amount of personal endeavor helps--a purely ragan conception. "They (the Zealots) also supposed that Ananus would be everywhere, and visit the guards every hour; which indeed was done upon other nights, but was onitted that night, not by reason of any slothfulness of Ananus, but by the overbearing appointment of fate, that so both he might himself perish, and the multitude of the guards might perish with him." (204)

Josephus' rationalism was thus the typical kind that characterized practically all the authors of his period. His system is interesting only inasmuch as it combined pagan and Hebraic conceptions of the nature of causes of historical events.

(202) (203)

Wars, i, 22, 1 and passim. (204) Ibid., i, 30,7 . 1 bid., iv, 4,6 . 


\section{E. Speeches}

In the manner of using speeches in his history, Josephus too represented the level method of his time. He made them to serve various purposes.

1. Where the author had the original body of the speech that the character spoke, he used it either as it was or with small change. Thus, a proclamation of Herod to Jerusalem (205) retains its original form. On the other hand, the speech of Nicolas of Damascus before Augustus, arguing Archelaus' right of accession, (206) seems to contain original material but reworked.

2. Speeches served to indicate the climax of a situation. Thus, the long oration of Agripps before the final decision of the people to commence the war was made to accentuate the significance of the immediately (207)

following act. The speech of Josephus before the walls of Jerusalem reminding the people of the possible consequences of their acts signified also the approach of (208) the coming climax. These speeches were originally delivered, but artificially reworked by the author in his study as regular orations. They are the central

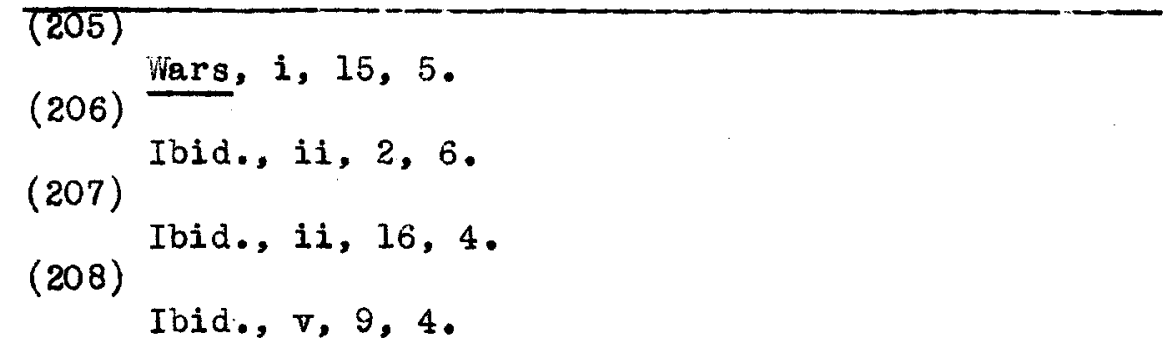


points that divide the history into a series of dramatic climaxes; they constitute fine specimens of oratory of Josephus' time.

3. Josephus also used speeches to indicate the motives of a man's action. In these cases, the speeches constituted the process of thinking out of the reasons and plans that were behind some important act of an individual. Antipater, in his struggle with his father, Herod, expressed his case well when speaking to his mother privately. (209)

4. Finally, there was a group of speeches that Josephus may have used to indicate his personal convictions. These were speeches of criticism put in the mouths of other people that in essence may yot have represented Josephus' orm point of view. Thus, he put a denouncement of Herod's character and reign in the (210) mouth of a third party; similarly, he ascribed a speech against the havoc the Romans wrought in Judaea to a (211) certain Eleazar.

\section{F. Chronology}

The matter of chronology affords a good check up on the care with which Josephus wrote his history. (209)

Wars, i, 30, 3 .

Ibid., i, 26, 2; i1, 6, 2 .

Ibid., Vil, 8, 6 . 
Nothing after all is as simple as ordinary arithmetic; and if one's writings were to be inconsistent even in that, it would show clearly a carelessness on part of the author.

Generally, Josephus took much pride in the exact chronology of the history of his people. It was in his opinion evidence of its trustworthiness.

In detail, however, his chronology is characterized by a confusion of various systems he was trying to follow simultaneously, and by a number of surprising inaccuracies. Thus, he dated the final attainment of independence by the Maccabees according to the Seleucid (213)

era, while a chapter later on he placed Aristobolus' resuming the diadem on another system--that of the Jewish (214)

return from Babylon. Simple inaccuracies also abound.

The Persian period, which actually lasted over two

centuries (537-333 B. C.), Josephus due to his failure of finding ample material to cover these centuries, presented the period to be of very short duration--not (215) more than half of a century. And yet when he was

Apion, 7 .

Vars, i, 2,2 .

Ibid., i, 3, 1 .

In fairness though to Josephus it should be mentioned that even the Rabbinic historical sources regarded the Persian period as of 34 years duration. 
on safer ground, he seemed to have grasped the real length of that period. Thus, he established that there were 481 years that elapsed between the return of the captivity and the time of Antiochus Eupator (537-164 3. C.); while a close figuring of his dates between these two limits does not yield that total. Similarly, it has been pointed out that "he gives the year of the flood as 2656, though the sum of the years of the Patriarchs who lived before it in his reckoning totels only 2256." Sohurer has shown that there are three different dates on the accession of Cyrus according to various statements (218)

of Josephus. "On the whole it seems impossible to deduce from Josephus a consistent system of chronology, or even to show that he had one, and in this respect his work is of a somewhat careless kind."

The problem of chronology is of course a baffling one at times even to modern historians. As such, it could hardly be expected of an ancient historian to have said the last word on it. But consistency and exact computation could have been fairly easy accomplishmonts for an historian. It might of course be said that Josephus' failure in this respect was due to his sources

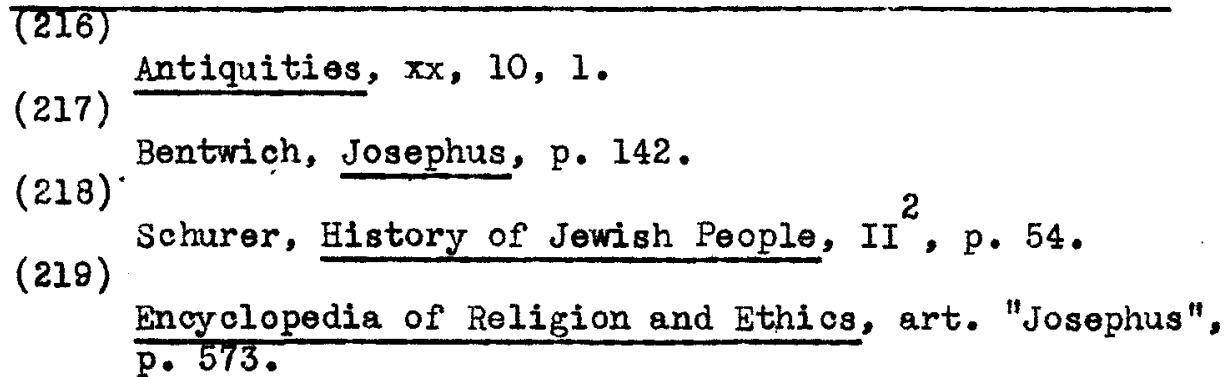


and not to his personal writing; but then it would only reveal the servility with which he copied them, without attempting to bring them into harmony.

$$
\text { G. Some Insolved Problems }
$$

There remain to be mentioned some general unsolved problems of importance that are at present occupying the attention of Josephean students, and which heve not as yet been entirely cleared up.

1. The most important of these problems is of course the renowned testimony to Jesus found in (220)

the Antiquities. The passage, small as it is, has evoked an enormous literature on the question of its authenticity. Opinions of scholars may be divided into three classes: Those who argue for the authenticity of the whole section, for partial interpolation, and those who are against the authenticity of the whole section. (221)

The importance of that testimony lies in its being the earliest reference extant to the founder of Christianity. Josephus wrote his history only some 50-60 years after the death of Jesus.

Antiquities, xvii, 3,3 .

Bibliography may be found in Schurer, History, $I^{2}$, p. 143-145; and in Judaism and BegInnings of Christianity, p. 231 . 
Generally, it may be said that the present opinion of scholars in regard to that passage is swinging between the secand and third positions, with a greater weight of authority inclining towards the latter view.

2. A recent problem which is now gathering great momentum is the discovery of a Slavonic Josephus, for which the claim is being made that it is a slavonio translation of the original Aramaio draft in which Josephus wrote the Wars. We remember that Josephus wrote his first work primarily for Jewish people, and the "barbarians" of the Euphrates, who spoke Aramaic. A work of that kind would naturally contain more genuine references to forms of Jewish life. Thus while in his Greek version Josephus hardly dared to mention the word Messiah, in an Arsmaic edition he would have naturally been more free to use such a term. The problem still awaits ample treatment. Eislor argues for the authenticity of the Slavonic text.

3. A third group of problems is that of Josephus * corroborating Jewish legal and traditional opinions. Josephus wrote in a time when Talmudic law was not as yet permitted to be written down. It was still regarded (222)

In his book The Messiah Jesus. 
as an oral law, to be practised by the people through the guide of its teachers. It was not codified until some hundred years after Josephus' death. When a comparison is then made between staternents of Josephus on law and their parallels in the Hishna and Talmud, certain discrepancies, though of minor nature, are found. The question then arises, are the Josephan statements early forms of these laws or are they simply mistakes due to ignorance? In general, evidence seems to point towards the latter conclusion, but the problem still awaits close investigation.

The same question may be raised in regards to the Haggadah, traditional material found in Josephus' version of the Bible's stories. These narratives contain almost in every cose certain legendary enbellishments, traces of which are found in the later Midrashic literature of Judaism. Questions of the same nature that have been raised in regard to the legal material are also of importance in the Haggadic field. 4. Finally, there is a large group of indirect references throughout Josephus' works which oover many items of importance--political, religious, social, Parthian, etc. A list of a fow of these indirect sidelights will show the scope they cover: 
There was an earthquake in the Near East

during the time of the battle of Actium.

Pelusium, off the coast of Palestine, was the (224)

seat of a Roman fleet in the Mediterranean.

Augustus' household servants exerted an indireot

influence on his political policies for the provinces.

There was a place in the Egyptian Delta that (226)

was called Jews' Camp.

In Damascus, Gentile women were under such Judaising influences that their husbands would not (227) trust them in a planned attack on the Jews.

A chapter in the inner history of Parthia is also to be found in the Antiquities. (228)

A reading of Josephus' history apparently offers part of its compensation in the many-sidedness of the world it portrays.

Wars, i, 19, 3 .

Ibid., i, 14, 2 .

Ibid., i, $32,6$.

Ibid., $i, 9,4$

Ibid., ii, 20, 2 .

Antiquities, xviii, 9, 1-9. 
IV. CONCEPTION OF HISTORY 
IV. CONCEPTION OF HISTORY

Anyone perusing the personal references of

Josephus in his history will be impressed by the facts that the author was very strongly conscious of his art as an historian, and of the credentials he brought to that profession. He could hardly bear the thought of someone daring to criticize him as to the truthfulness of his accounts.

"How impudent then must those deserve to be esteemed that undertake to contradict me about the true state of those affiars!" (229)

He would never tire of pointing out the qualifications that enabled him to become the historian of his poople. (230)

In a way, Josephus made these statements in defense of his "magnum opus", the Antiquities. The work had aroused a storm in the literary circles of Rome. For an author to come forward and claim such excellence and remote antiquity for the Jews-mand this at a time when after the Destruction no one had to say a good word for them-was a daring act that could not be left to go unchallenged. Josephus was henoe attacked from both personal and professional sides. In defense of these (229) (230) $\frac{\text { Apion, p. } 10}{\text { Ibid., p. } 9 .}$ 
assaults, Josephus for the one time in his life boldly stepped forward to speak out his personal conviotions; the result was his Contra Apion, in the discussion of which he occasionally turned aside to voice his opinions on some general conceptions of history.

A. Criticism of Greek Historiogrephy

An easy way of defending one's own cause has

always been to commence with an attack on the opposing side. Josephus was prone not to neglect any opportunity. Accordingly, he had some pointed marks to say on general Greek histo riography.

The conspicuous defect from which Greok historiography suffered was, according to Josephus, the scarcity of any good foundation for its early period. Having taken no care to preserve public records, the Greeks could point to no written sources either in Temples or on public monuments to illumine the early course of events of their history. Prior to Homer's period, there was not any writing which is agreed to be genuine; and even of his epics, "the report goes, that he did not leave his poems in writing, but that their memory was preserved in songs, and they were put together afterward, and that this is the reason of such a number of variations as are found in them." (231) (231) Apion, p. 2. 
The cause of this deficiency of Greek historiography goes back, in the opinion of Josephus, to a fundamental characteristic of Greek life--nomely, that it had not developed the proper esteem for history as a science of great importance. Among the Egyptians and all Semitic peoples "their history was esteemed sacred, and put into publio tables, as written by men of the greatest wisdom they had among them." (232) In Greece, this development never took place. As a result, history remained an individual science, to be written by people who wanted to serve their personal interests. "Their business was to demonstrate that they could write well and make an impression upon mankind thereby." (233) Thucydides who seems to have given us the exactest history of the affairs of his times "is accused of some as writing what is false." (234)

We might say that Josephus made here the point that among the Egyptian and Semitic peoples, history enjoyed an official position in the state; among the Greek people, it never rose to that level, but was left to its fate, shifting aimlessly for its existence and depending upon individuals to volunter to enter the (232) Apion, p. 2. (234) Ibid., 5 . Ibid., 3. 
service of its cause. When they finally did so, no Greek would care to examine the historians' credentials or determine the exactness with which they wrote their histories.

Hence, the levity of the Greek's regard for his own history. "He takes it to be merely a discourse as framed agreeably to the inclinations of those that wrote (235)

them, but of no serious meaning. No Greek would therefore be willing to undergo the least personal harm if he were to see all the histories of his people put (236) to fire. But compare the case in countries where "not everyone is permitted of his own accord to be a writer....they being only prophets that have written the original and earliest accounts of things", (237) and it is possible to understand why a people of that kind would have a sacred regard for history.

"Time and again ere now the sight has been witnessed of (Jewish) prisoners enduring tortures and death in every form in the theatres, rather than utter a single word against the laws and the allied (historical) documents.

$$
\begin{aligned}
& \text { (236) } \frac{\text { Apion, } 8 .}{\text { Ibid. }} \\
& \text { (237) } \\
& \text { Ibid., } 7 .
\end{aligned}
$$


What Greek would endure as much for the same cause?

Even to save the entire collection of the nation's writings from destruction he would not face the smallest personal injury. For to the Greeks they are mere stories improvised according to the fancy of their authors." (238)

The world thus has to learn from Greek historiography "only style and eloquence of composition" but nothing as to verity and attitude. B. History as It Should Be Written History then is a science that demands great requirements of tho se who enter its profession. In perticular, these requisites are as follows.

The historian must have been either a participant in the affairs he describes or to have had first-hand information from those that knew them. "Everyone that undertakes to deliver the history of actions truly ought to know them accurately himself in the first place, as either having been concerned in them himself, or been informed of them by such as know them."

He must be equipped by his early education to understand the Iife and nature of the people he takes (238)

$$
\begin{aligned}
& \text { Apion, } 8 . \\
& \text { Ibid., } 10 .
\end{aligned}
$$


as his theme.

(240)

Before commencing to write, the historian

must first gather all possible materials for his work.

There must be special attention given to treating sources (242)

with accuracy. Honesty in presenting the theme as

it appears to the historian, without adding or distracting

any particulars from it, is the next imperative require-

ment. (243)

After accuracy and honesty comes style. "Among other qualifications the kistoriar......needs charm of style, in so far as this is attainable by the choice and combination of words and whatever else may serve to embellish the narrative for his readers, in order that the instruction may be attended by a certain fascination and pleasure; but, above all, he mist aim to speak accurately, and to speak truly." (244)

(240)

Apion, 10.

(244)

Ibid.. 9.

Antiquities, xiv, 1, 1 .

Ibid.

Ibid., $x x, 11,2$. 
Deduction of ethical precepts and philosophical implications from the course of historical events is a legitimate and partial task of the historian.

(245)

In its final form, a true history is recognized by the stamp of consistency of the view it bears, and by the universal agreement it evokes. "The proof of historical veracity is universal agreement in the description, oral or written, of the same events."

Finally, the historian must permit his work to go through the study of competent critics and authorities to receive their commendation. (247) It is only then that the history can be placed before the public.

C. Assistants. Style. Literary Value

From the nature of this brief sketch of Josephus' thoughts on the writing of history, we are justifled in inferring that he had a high regard for his art. Further indications of style and literary merits point to the same conclusion.

Josephus wrote his history in Greek. But as his knowledge of that language from his youth could not have been any too profound, he admitted (248) of having obtained

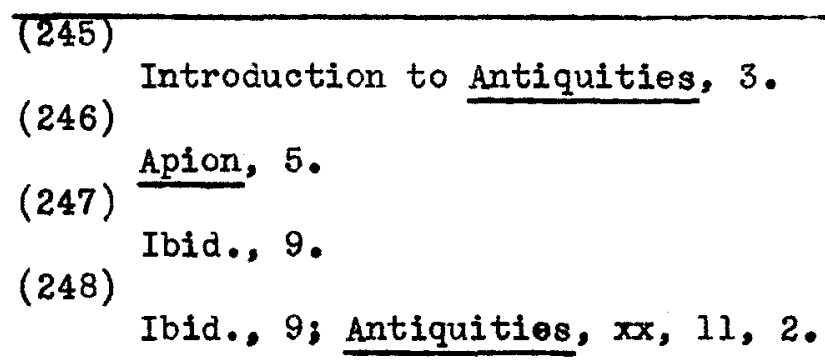


assistance--"employed collaborators for the sake of (249)

Groek style." Thackeray has carefully traced the hands of at least two distinct assistants in Josephus' works: one, an involved Thucydidean style, characterized by an extravaganoy of expression, and the other, of a pure classical Greak style. He has also traced the influence of general olassical Greek and Roman literature on certain portions of Josephus' history.

The effect of Josephus' style he expresses in the following words. "Considered as a literary work the Jewish War as a whole possesses great merits. The style is an excellent specimen of the Atticistic Greek fashionable in the first century, introduced by the school which sought to stem the development of the language that set in with the Alexandrian age and to revive the Attic of the age of Pericles. A choice vocabulary, well-knit sentences and paragraphs, niceties in the use of partioles and in the order of words, a uniformly classical style but without slavish imitation of classical models"-- these and other excellences are characteristic of the War. The style of the Antiquities, on the other hand, represents the work of both assistants. In portions where

Judaism and Beginnings of Christianity, art. "Josephus", pp. 198-210.

Josephus, Vol. II (Loeb Classical Library), pp. xii-xiv. 
the Thucydidean collaborator was at work, "the old Grecian battles are refought, orations of Perioles (251)

redelivered on Palestinean soil; while in other portions, the purity of the style of the War is again marked.

The literary value of Josephus' history as a whole stands on no lower plane than his style. For whatever might be said on the euthor's shortcomings as to lack of discrimination in using sources, harmonizing motives, etc.. his work as it is before us is a moving and picturesque narrative. He built his story in descriptive conorete pictures. His exact descriptions of natural phenomena, geographical divisions of Palestine, fortresses, sieges, battles, have the effect of placing the scenes and events right before the reader's eye. In adition, he had a fine sense of irony. Thus, Archelaus "lest he should be in danger of not being thought the genuine son of Herod" with the murder of 3,000 citizens. We might then conclude that what Josephus lacks on close examination, he makes up with a vividness of (251) (252)

Thackeray, Josephus the Historian, p. 111. Wars, ii, 6, 2 . 


\section{1}

his theme as a whole. That clearness is of course only an external quality, but its effect novertheless is of raising to life the age he described. 
V. RELATIVE POSITION OF JOSEPHUS AMONG CLASSICAL HISTORIANS 
V. RELATIVE POSITION OF JOSEPHUS AMONG CLASSICAL HISTORIANS

It is to the credit of Josephus that when placed amidst the other renowned historians of antiquity, he does not fall short of their standards. For while he was assuredly no historian of the first rank, he may yet be found mentioned in the same breath with Dionysius of Halicarnassus, Dio Cassius, Appian -- historians of note with all of whon he measures up quite favorably. Josephus, due to the Greek language in which he wrote his history, belongs to the Hellenistic historiens, who continued their traditions throughout the period of the Roman Empire. They constituted a school that was characterized by its Atticism, a tendency to classicize, "imitating the great ancient writers instead of striking out new lines of thought or expression." (254) Unlike other movements of imitation, however, this tendency proved quite successful. (255)

In addition to its Atticism, the school was marked by a certain flatness, an inability of rising to genuine heights of inspiration that would produce some outstanding master historians. The cause of this decline may be explained by the fact that the early great historians

Encyclopedia Brittanica, art. "Greek Literature", p. 837.

$$
\text { Ibid. }
$$

Ibid. 
of Greece emerged from a background that was distinctively Greek in the spirit of life, while "the Hellenistic writers, subjects of Empires that were none of their own creation, had no longer a community which they could symbolize." ${ }^{(256)}$ Hence the histories of even the best of these writers fall quite short of greatness. Dio Cassius, e.g., "whose history though is by far more than a mere compilation is yet not remarkable for impartiality, vigor of judgment, or critical historical faculty." (257)

It was similarly true of the entire group of Hellenistic historians amidst whom Josephus stood, namely, Doinysius of Halicarnassus, Dio Cassius, Arrian, Appian, Eerodian, Eusebius, and Zosimus. They all embodied improvements in technical skill, and in the manner of presenting lively accounts of external events, but failed in the greater requirements of first-class histories.

A comparison with the Latin group of historians is also of importance; not so much because of Josephus wrote in Rome, but due to the fact that he was a contemporary of Tacitus, one of the greatest of Roman historians. Generally, the period in which Josephus wrote, the silver Age, was in many respects similar to the Hellenistic Poriod in Greek liberature. (258) Tacitus (256)

Encyclopedia Brittenica, art. "Greek Literature", p. 837. Ibid., art. "Dio Cassius", p. 392. Ibid., art. "Latin Literature", p. 751. 
was the only exception to the mediocrity of that age;

he is indeed considered as one of the greatest historians of all times.

The question of the influence that the two historians exerted upon one another, particularly since Tacitus in his Histories narrated Jewish events that were within the field of Josephus, is a problem to which only conjectures (259)

can be made. However, one cannot fail to note that certain fundamental conceptions we have met in Josephus' history are also to be found in that of Tacitus, namely, the concept of underlying principles of moral law in history, the manner of external objectivity with which they claim to have written their histories while in reality they were moved by certain interests. Concluding the consideration of Josephus' relative position among classical historians, we might say that in form and manner he was completely submerged in the classical environment. In other words, what we have seen to be true of his life and character, namely, that their roots went deep down into the Judaean environment, is conversely true of him as an historian--namely, that it went deep down into the Greco-Roman World. 
VI. SUMNARY 
VI. SUMMARY .

It is difficult to appraise the works of Josephus. History itself has varied its verdict on them. Enjoying reputation during the Empire as part of the standard literature, treasured as a kind of introduction to the Gospels during the early Christian period, carefully preserved throughout the stormy Middle Ages because of their celebrated testimony to the founder of Christianity. and still highly venerated through the Renaissance period up to modern times--his works enjoyed an authority almost next to that of the Bible. Nor was the historien overlooked in this wave of admiration. Rome itself erected his statue after his death. (260) Cassiodorus called him "almost a (261) second Livy; Scaliger of the Italian Renaissance regarded him as superior to any pagan historian; and his popularity reached even Rembrandt, as is seen from the painter's naming a portrait after Josephus. Only students of his own people doubted the truthfulness of his history. During the Empire and early Middle Age periods, they forgot him entirely; his history was rediscovered by them not until the revival of Jewish literature in Spain and North Afrioa. A characteristic of him made by the famous Isaac Abranbanel of the fifteenth century reads as follows.

\footnotetext{
(260)

See the sources quoted in Eisler's The Messiah Jesus, p. 29, n. 1-2.

Quoted in Bentwich, Josephus, p. 245.
} 
"In many things he (Josephus) perverted the truth, even where we have the Scriptures before us, in order to court favor with the Romans, as a slave submits himself to the will of his master." (262) Moderm criticism, as has been seen throughout this entire paper, is inclined to accept, though not entirely, the Jewish view. It has arrived at this conclusion from the standpoint of a consideration of both the author's life, and from the manner in which he exeouted his profession as a historian. His activity was far from being candid. He remained through his life self-centered and self-interested. In a heroic age of Jewish trenuous endeavor, centering at first in the struggle against Rome, and then in the Restoration at Jabneh--he remained a selfseeking, complacent type of man. And as an historian "the client in him prevails over the historian: we con never be sure whether he is expressing his own opinion or only what he conceives will be pleasing to his patrons and masters." (263)

Yet, in faimess to the man as an historian, his great service to history must be taken into account. He is after all the sole authority extant for an age that is of colossal importance to the history of the world.

Quoted in Bentwich, Josephus, p. 253.

Ibid., p. 256 . 
The times and circumstances in which he wrote help to explain many of his defects and shortcomings. And wile when examined individually, and held up to close scrutiny, he can hardly pass the test of greatness, yet when placed in the entire company of historians of the Silver Age, he may well be said to have been--a first-rate historian of a second-rate age. 
BIBLIOGRAPHY 


\section{BIBLIOGRAPHY}

I. Writings:

Josephus, Flavius. Life and Works, translated by

William Wiston, Winston Company,

Philadelphia, New Jersey.

Josephus, Flavius, ed. H. St. John Thackeray (Loeb

Classical Library), Putnam, New York, 1926.

Volume I: The Life and Against Apion

Volume II: The Jowish War, Books 1-3.

Volume III: The Jewish War, Books 4-7.

Volume IV: The Antiquities, Books 1-4.

II. Sources:

Bentwich, Norman. Josephus. Jewish Publication Society, Philadelphia, 1914.

Bloch. Die Quellen des Flavius Josephus. Leipsic, 1879.

Destinon. Die Chronologie des Josephus, Kiel, 1880.

Destinon. Die Quellen des Flavius Josephus in der Judishe Archaelogie, Kiel, 1882 .

Jackson, Foakes. Josephus and the Jews, Richard Smith Publishers, New York, 1930.

Krauss, Solomon. Josephus in Jewish Encyclopedia, Funk and Wagnalis, 1903.

Laquer, Richard. Der judische Historiker Flavius Josephus, Giessen, 1920.

Niese, Benedictus, Josephus, in Hastings Encyclopedia of Religion and Ethics. Scribners, New York, 1915.

Rappaport, Solomon. Agada and Exegese bei Flavius Josephes. Alexander Kohut Foundation, Vienna, 1930.

Thackeray, H. St. John. Josephus the Man and Historian. Jewish Institute of Religion Press, New York, 1929.

Thackeray, H. St. John. "Josephus" in Judaism and Beginnings of Christianity. Bloch Publishing Company, New York, 1924. 
III. References:

Bentwich, Norman. Philo. Jewish Publishing Society, Philadelphia, 1912 .

Bevan, E. R. Jerusalem under the High Priests, London, 1924.

Bevan, E. R. Hellenistic Judatsm in The Legacy of Israel. Clarendon Press, Oxford, 1927.

Box, H. Pharisee in Hastings Encyclopedia of Religion

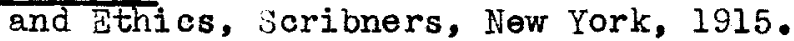

Cohen, A. Jewish History in the First Century in Judaism and Boginnings of Christianity. Bloch Publishing Company, New York, 1924.

Dubnow, S. Diviei Yernai Ave Olam, Vol. 2, एviy Publishers, Dviv, Palestine, 1930.

Drubnow, S. Jewish History, Jewish Publishing Society, Philadolphia, 1927.

Elsler, Robert. The Messiah Jesus. Dial Press, New York, 1931.

Encyclopedia Brittannica, art. Greek Literature and art. Latin Literature. Encyclopaedia Brittannica Inc., 14th Edition, 1929.

Ginsberg, I. The Religion of the Pharise日 in Students, Scholars, and Saints. Jewish Publishing Society, Philadelphia, 1928.

Graetz, Heinrich. The History of the Jews, Vol. 2 . Jewish Publishing Socioty, Philadelphia, 1891.

Halevy, I. Doroth Harishonim, Vols. 1-2. Harz Verlag, Berin, 1922.

Herford, R. T. Pharisaism, Its Aim and Method. Bloch Publishing Company, New York, 1912.

Herford, R. T. The Pharisees. Bloch Publishing Company, Now York, 1924.

Herford, R. T. The Significance of Pharisaism in Judaism and Beginnings of Christianity. Bloch Publishing Company, New York, 1924. 
Klausner, J. Jesus of Mazareth. Macmillan Company, New York, 1925.

Klausner, J. Beth Hasheni Begadluso. Dvir Publishers, Tel Aviv, Palestine, 1930.

Mommsen, Theodore. Judaea in Provinces, New York, 1887.

Thoore, George poot. Judaism, Vol. 1. Harvard Press, Cambridge, 1927.

Radin, Max. The Jews Among the Groeks and Romans. Jewish Publication Society, Philadelphia, 1916.

Renan, Ernest. History of Israel, Vol. 5. Boston, 1907.

Shotwell, J. Josephus in Introduction to History of History. Columbia, New York, 1923.

Tacitus, Cornelius. Histories, translated by H. Clifford Woore, G. P. Putnam's Sons, 1925.

Naxman, Meyer. Hellenistic Literature in A History of Jewish Literature. Bloch Publishing Company, Now York, 1929.

Weiss, I. Dor, Dor Vedorshov, Vols. 1-2. Platt and iinkus, Berlin, 1924.

Yavitz, Wolf. Toldoth Israel, Vols. 5-6. Graditzki Publishing Company, London, 1912. 